\title{
THE AFRICAN MINING VISION: PERSPECTIVES ON MINERAL RESOURCE DEVELOPMENT IN AFRICA
}

\author{
Kojo Busia* \\ Charles Akong**
}

\begin{abstract}
This article argues that, after the recent boom, the African Mining Vision (AMV), upon making development central in the extractive industry, is a paradigm whose time has come. We hypothesize that the Vision is forwardlooking with a robust ideational foundation, able to seize emerging policy windows towards lasting paradigm shift for Africa's extractive sector. The article presents a dynamic framework for analysing policy change in the extractive sector in Africa, based on the power of ideas and interests networks. While the crisis in the sector presents an opportunity, the article analyses the binding political economy constraints that African governments would have to overcome at the global, regional and country levels to implement the transformative ideas of the AMV. The article presents a matrix systematically analysing possible scenarios for implementing the Africa Mining Vision. The implementation of the AMV would likely be non-linear. Vested interests, including resistance to change and diversity of country contexts, could lead to varied outcomes in the implementation of AMV in the short and medium terms.
\end{abstract}

Keywords: Africa Mining Vision, ideas, interest's networks, extractives sector, commodity booms.

DOI: https://dx.doi.org/10.4314/jsdlp.v8i1.7

\section{INTRODUCTION}

Mineral-rich Africa faces its strongest ever headwind with the adoption of the Africa Mining Vision (AMV) in 2009. The prolonged fall in

\footnotetext{
Coordinator, African Minerals Development Centre (AMDC).

$* * \quad$ Economic Affairs Officer, Team Leader, Linkages Diversification and Investment, African Minerals Development Centre (AMDC).
} 
commodity prices presents a challenging environment for implementing the vision. The endorsed continental framework aims to bring about a "transparent, equitable and optimal exploitation of mineral resources to underpin broad-based sustainable growth and socio-economic development". ${ }^{1}$ Demand-side factors driven by slowdown of growth in China, which consumes over 50 per cent of all metals, as well as industryspecific forces underpinned by oversupply and competition for market share, together have significantly weakened mineral prices, since their recent high of $2011 .^{2}$

The depressing volatility is hardly a new phenomenon. Commodity prices oftenrise and fall in painful patterns of vulnerability, risks and crises. ${ }^{3}$ The sharp and prolonged nature of the current fall in prices has provoked a rethink of the ideational foundation of governance in Africa's extractive sector. While it remains unclear for how long prices will stay very low, the slump is already revealing a fundamental crack in the externally-driven revenue-first model, which has continued to mark mining regimes in Africa with its unrealistic assumption of sustained high commodity prices.

The adoption of a continental strategy is to do business differently, integrating the broader extractive industry into the local, national, regional and global value chains. As a new initiative, the AMV is building its credibility as a transformative framework, competing with other long-established regimes in the sector. The falling commodity prices and the ensuing fiscal crises are challenging many mineral-rich African countries. At the same time, many more African countries are entering the league of mineral-rich and dependent countries with massive discoveries of oil, gas and minerals. It remains unclear whether the development orientations embodied in the vision are robust enough for countries to adopt the strategies without scaring away needed external investors. Yet given its holistic focus, the depressing context makes it even more imperative to advance the implementation of the long-term development priorities of Africa's mineral sector, consistent with the post-2015 development agenda.

1 The African Union Commission, “The Africa Mining Vision" (2009), p. 1.

2 The World Bank, "Commodity Markets Outlook" (October 2015), Washington D.C.

3 Bain, A., "The New World of Crises and Crises Management: Implications for Policy Making and Research", Review of Policy Research (2013), 26(4), pp. 367377. 
This article argues that, after the boom, the AMV focus on putting development front and centre in the extractive industry is imminent. Our central hypothesis is that the vision is forward-looking enough with robust ideational foundation for seizing emerging policy windows to bring about lasting paradigm shift for Africa's extractive sector, anchored on its broad-based development. The assumption guiding the analysis is that ideas matter in policy change and to the extent to which they organize interests, actors, as well as create power and seize opportunities presented for change. We also take for granted that crises generate "framing contests", including varied interpretation of events, their causes, responsibilities and lessons learned for informing and shaping the path of future policies.

We contribute to the growing literature on ideas and policy change. There are sparse number of studies that systematically explore the dynamics of idea formation, as well as crises and regime change in the extractive sector. Fewer have focused on the hierarchy of change both in substantive and procedural terms - clearly distinguishing between shifts in normative ideas and implementation mechanisms. As an overall objective, the article analyses the options for establishing AMV as an enduring paradigm capable of effectively responding to boom and bust cycles of commodity markets. We adopt a discursive institutionalist approach, framing ideas as sources of power for policy change. We specifically adopt a conceptual framework for assessing the emerging contextual dynamics for implementing the AMV.

The remainder of this article is organized as follow. Section 2 reviews the literature on the role of ideas in mining regimes, providing the theoretical arguments used in building the conceptual framework underpinning this article.Section 3 presents the Africa Mining Vision as a new social contract. The conceptual framework presented in section 4 is then employed in section 5 to analyse the challenges and opportunities presented by the current crises facing the sector in Africa. Section 5 also evaluates the different permutations or scenarios of change, while section 6 is the conclusion.

\section{UNDERSTANDING THE POWER OF IDEAS IN MINING REGIMES}

Change remains a permanent fixture of life, goes a popular adage. Public policy-making is oftenmarked by continuity and stability, with change 
occurring rarely and incrementally. ${ }^{4}$ In explaining the mechanics of change and evolution in public policies, several studies have underscored the role and influence of ideas. ${ }^{5}$ Flathman (1966) notes how the ideas that policy makers hold influence decision making. ${ }^{6}$ In studying policy change, the concept of policy paradigm has been applied widely in many sectors and fields. ${ }^{7}$ Basically, the term captures established beliefs, values and attitudes behind framing of public policy problems. ${ }^{8}$ Paradigm shifts occupy one-end of a continuum describing the potential power of ideas. ${ }^{9}$

In his seminal work on policy change in Britain, Peter Hall argued that policy paradigms establish the broad goals behind policy, the related problems or puzzles that policy-makers want to solve and the kind of instruments to achieve the goals set for the policy. ${ }^{10}$ Individuals in a policy subsystem hold a "deep core" of basic values and beliefs

4 Wolfgang Streeck \& Katheleen, Thelen, "Introduction: Institutional Change in Advanced Political Economies", in Wolfgang, Streeck and Katheleen Thelen, Beyond Continuity: Institutional Change in Advanced Political Economies (eds) (OUP, 2005); Charles Lindblom, The Science of Muddling Through. Public Administration Review, 19 (1959), pp. 79-89; Paul Schulman, "Non-incremental policy making: Notes toward an alternative", American Political Science Review, 69 (1975), pp. 1354-1370.

5 Daniel Beìland, Martin B. Carstensen and Leonard Seabrooke, "Ideas, Power, and Public Policy," Journal of European Public Policy, 23 (3) (2016), pp. 315317; Elizabeth Shanahan, Michael Jones and Mark McBeth (2011). "Policy Narratives and Policy Processes", Policy Stud. J. 39 (2011), pp. 535-561; Frank Baumgartner and Bryan Jones, "Agenda Dynamics and Policy Subsystems", The Journal of Politics, Vol. 53, No. 4 (1991), pp. 1044-74; John Kingdon, "Agendas, Alternatives and Public Policies" (University of Michigan 1984).

6 Richard Flathman, The Public Interest: An Essay Concerning the Normative Discourse of Politics (New York: Willey, New York, 1996).

7 Mark Carson, Tom Burns and Dolores Calvo, Paradigms in Public Policy: Theory and Practice of Paradigm Shifts in the EU (Peter Lang Publishers, Berlin, 2009); Pierre-Marc, "Reassessing the Concept of Policy Paradigm: Aligning Ontology and Methodology in Policy Studies", Journal of European Public Policy, 21:3, (2014), pp. 453-469; Matt Wilder, "Ideas beyond Paradigms: Relative Commensurability and the Case of Canadian Trade-Industrial Policy, 197595," Journal of European Public Policy, 22: 7(2015), pp. 1004-1021.

8 Erving Goffman, "Frame Analysis: An Essay on the Organization of Experience" (Havard University Press 1974).

9 Frank Baumgartner, "Ideas, Paradigms and Confusion", in Journal of European Public Policy (2014) 21:3, pp. 475-480.

10 Peter Hall, "Policy Paradigms, Social Learning and the State: The Case of Economic Policy Making in Britain in Comparative Politics" (1995) 25, 3, pp. 275-96. 
that inhibits anything but marginal changes to programme ideas and policy contents. ${ }^{11}$ What constitutes policy change and how it occurs, therefore, remains central to its analysis.

Occasionally, the staying power of ideas encapsulated in paradigms breaks down as a result of replacement of one identifiable coherent set of ideas with another. ${ }^{12}$ Paradigm shifts are complex and dynamic processes. John Kingdon, a towering scholar of public policy, emphasizes the time dimension of policy change, arguing that some ideas become fashionable at specific points in time and context as ideas whose time has come. ${ }^{13}$ The unpredictable nature of ideational change has also preoccupied scholars. Policy change, according to Albert Hirschman, "occurs as a result of surprise, otherwise it would be suppressed by forces that are in favour of the status quo". ${ }^{14}$ Continuity is therefore not given but wilfully maintained. ${ }^{15}$

Random and perceived disruptive events are important drivers of paradigm shifts. The role of exogenously induced shocks in policy change has long been widely studied. ${ }^{16}$ The link between crises and reforms is very strong in economic literature. ${ }^{17}$ The disruptive event is defined as

11 Paul, Sabatier, "An Advocacy Coalition Framework of Policy Change and the Role of Policy-Oriented Learning in Policy Sciences" (1988), 21, 2: 3, 129-68.

12 Mathew Wood. 2015. "Puzzling and Powering in Policy Paradigm Shifts: Politicization, Depoliticization and Social Learning in Critical Policy Studies" (2015), 9:1, pp. 2-21, p. 10.

13 John Kingdon, "Agendas, Alternatives and Public Policies" (University of Michigan 1984), p. 3.

14 Albert Hirschman, "Propensity to Self-Subversion" (Harvard University Press 1995), p. 10.

15 David Dery, "Agenda Setting and Problem Definition", Policy Studies, Vol. 21, No. 1 (2000).

16 Giandomenico Majone. 1989. "Evidence, Argument, and Persuasion in the Policy Process" (Yale University Press, New Haven, 1989); Thomas Birkland (1997). "After Disaster: Agenda Setting, Public Policy and Focusing Events" (George Washington University Press, Washington, 1997); Mark Blyth, "Great Transformations: Economic Ideas and Institutional Change in the Twentieth Century" (Cambridge University Press, 2002); John Hogan \& Sharon Feeney, (2012). "Crisis and Policy Change: The Political Entrepreneur". Risks, Hazards and Crisis in Public Policy, Volume 3, Issue 2, Article 6 (2012).

17 Aaron Tornell, "Economic Crises and Reforms in Mexico". In Vitrolio Corbo, Latin American Macroeconomic Reform (Chicago University Press, 2003) pp. 127-150; Romain Rancière \& Aaron Tornell, Why do Reforms Occur in Crisis Times (IMF Working Paper, 2015). 
a critical juncture during which major change is possible. ${ }^{18}$ From a systemic perspective, Coyne defines crisis as unexpected event that creates uncertainty and poses a direct or perceived threat to the goals and norms of an organization, institutions and society. ${ }^{19}$ Crises do not occur in a vacuum on their own; they are often precipitated by some events or shocks to the system. ${ }^{20}$ Notably, the definition of crisis as externally induced events remains limited and too deterministic. It discounts the role of endogenous factors.

Open windows of opportunity remain crucial to turn ideas into policy change. Ideas do not only remain floating and waiting for crisiswindows to open, they in themselves can also create opportunities for change. ${ }^{21}$ Kingdon identifies the existence of at least four possible windows: routinized political windows, discretionary windows, spillover windows and random problem windows. ${ }^{22}$ Along a continuum of institutionalization and predictability, crises-driven events as exogenous shocks occupy one end of the predictability spectrum. ${ }^{23}$ The nature of crises has changed over the last decade, becoming more and more transboundary in reach, crossing sectors, regions and countries. ${ }^{24}$ Crises have become more systemic, marked by a high degree of complexity, uncertainty, ambiguity as well as urgency. ${ }^{25}$

Yet not all policy change is the same. Based on instruments and goals, Peter Hall examines the scale of ideational change and organized them into three levels: first order change which are routine adjustments

18 Michel Gorges, "The New Institutionalism and the Study of the European: The Case of the Social Dialogue". West European Politics, 24(4), (2001), pp. 152168 , p. 155.

19 Christophe Coyne, "Constitutions and Crisis". Journal of Economic and Behavioral Organization (2011), pp. 351-357.

20 Peter Grossman, "Energy Shocks, Crises and the Policy Process: A Review of Theory and Application", Energy Policy, Vol. 77, pp. 56-69 (2015).

21 Vivien Schmidt, "Discursive Institutionalism: The Explanatory Power of Ideas and Discourse", The Annual Review of Political Science, 11 (2008), pp. 303-26.

22 John Kingdon, "Agendas, Alternatives and Public Policies" (University of Michigan 1984), p. 3.

23 Ibid.

24 Arjen Boin (2009). "The New World of Crises and Crises Management: Implications for Policy Making and Research", Review of Policy Research, 26(4), (2009), pp. 367-377.

25 OrtwinRenn, Andreas Klinke \& Marjolein Van Asselt " "Coping with Complexity, Uncertainty and Ambiguity in Risk Governance: A Synthesis", Ambio, 40(2), (2011), pp. 231-246. 
to existing policies; Second order changes in the policy instruments used to achieve shared goals; and third order changes in the hierarchy of goals themselves. ${ }^{26}$ The first two orders of change tinker around policy mechanisms while the last involves substantive changes in policies, including normative claims.

Meanwhile, ideas on their own rarely transform themselves into policy change. They operate in a context, underpinned by agency. Recent studies in public policy continue to emphasize the role of agency through long-term patterns of policy processes as well as policy paradigms. In fact, policy style and policy content combine to form policy regime ${ }^{27}$ Policy regimes have been used in different ways including political, international and implementation regimes. ${ }^{28}$ Irrespective of the meaning and confusion, the term regime addresses some core criticisms against the use of ideas as the overarching variable in policy change, by underlying the role of actors, institutions and interests. ${ }^{29}$ Policy regime, therefore, provides an analytical concept for capturing long-term patterns of processes and policy content.

The first generation of ideational scholarship eloquently underscores the role and mechanism in which ideas matter. The literature collectively provides an interpretive framework through which ideas give meaning to value, preferences that make political and economic interest actionable. ${ }^{30}$ Observably, how ideas in themselves can generate power to bring about policy change, evolution or stagnation is often assumed than explained. Some scholars argue that the possession and promulgation of ideas that serve to define a given moment of crisis

26 Peter Hall, "Policy Paradigms, Social Learning and the State: The Case of Economic Policy Making in Britain", Comparative Politics, 25, 3 (1993), pp. 275-96.

27 Micheal Howlett \& M. Ramesh, Studying Public Policy: Policy Cycles and Policy Subsystems, Second Edition (Oxford University Press Canada, 2003).

28 Stephen Krasner, "Structural Causes and Regime Consequences: Regimes as Intervening Variables", International Organization, 36/2 Spring (1982), pp. 185-205; Robert Stocker, "A Regime Framework for Implementation Analysis", Policy Studies Review, 9, 1 (1989); Lee Preston, \& Duane Windsor, The Rules of the Game in the Global Economy: Policy Regimes for International Business (Kluwer Academic Publishers, 1992).

29 Micheal Howlett \& M. Ramesh, Studying Public Policy: Policy Cycles and Policy Subsystems, Scond Edition. Oxford University Press Canada, 2003).

30 Daniel Beland, Martin Carstensen \& Leonard Seabrooke, "Ideas, Political Power and Public Policy", Journal of European Public Policy, Vol. 23, Issue 3 (2016), pp. 315-317. 
and project the institutional forms that will resolve it becomes a crucial power resource. ${ }^{31}$

Power, in general, is a relational and multidimensional concept. Traditionally, power in the social sciences has been framed as the ability to achieve one's aim amidst resistance. ${ }^{32}$ This however, goes beyond material resources. It involves symbolic and normative resources in addition to structures and institutions. ${ }^{33}$ Foucault conceptualizes the relationship between power and ideas and how they are used as a form of social control. According to him, power is socially constructed - the omnipresence of power is not based on its privileging a particular position in relation to others, but that it is produced from one moment to the next, at every point, or rather in every relation from one point to another. ${ }^{34}$

Recent scholarship has examined ideational power as an independent analytical concept in its own right, similar with other forms of power. ${ }^{35}$ Ideational power is "the capacity of actors (whether individual or collective) to influence actors' normative and cognitive beliefs through the use of ideational elements." ${ }^{\prime 36}$ The literature therefore conceptualizes ideational power in a much more specific and dynamic way than the more generic claim in the public policy literature that ideas matter on their own. ${ }^{37}$ Ideational power therefore should produce particular kinds of effects through unleashing agency on an agencyoriented approach. ${ }^{38}$ Carstensen and Schmidt theorizes ideas and power

31 Mark Blyth, "Great Transformations: Economic Ideas and Institutional Change in the Twentieth Century" (Cambridge University Press, 2002) p. 4; Robert Cox, "The Social Construction of an Imperative: Why Welfare Reforms Happened in Denmark and the Netherlands but Not in Germany", World Politics 55(3) (2001), pp. 463-498.

32 Max Weber. 1968. Economy and Society: An Outline of Interpretive Sociology (Bedminister Press, New York, 1968).

33 Robert Dahl, "The Concept of Power", Behavioral Science, 2(3) (1957), pp. 201215.

34 Michel Foucault. 1978. "The History of Sexuality, translated by Robert Hurley," Vol 1 (Pantheon New York 1978), p. 93.

35 Martin Carstensen \& Vivien Schmidt, "Power through, over and in Ideas: Conceptualizing Ideational Power in Discursive Institutionalism", Journal of European Public Policy, Vol. 23, Issue 3 (2016).

36 Ibid, p. 319.

37 Micheal Howlett \& M. Ramesh, Studying Public Policy: Policy Cycles and Policy Subsystems, Second Edition (Oxford University Press Canada, 2003).

38 Michel Barnett \& Duvall Raymond, "Power in International Politics", International Organization, 59 (4), (2005), pp. 39-75. 
in three dimensions. ${ }^{39}$ First, power through ideas, which is the capacity of actors to persuade other actors to accept and adopt their views of what to think and do through the use of ideational elements. Second, power over ideas, which is the imposition of ideas by agents and the power of actors to resist the inclusion of alternative ideas into the policy making process. Third, power in ideas, which is exercised through the use of structures and institutions to establish a hegemony over the production of ideas or constraining what ideas may be considered in the policy-making process and implementation. ${ }^{40}$ Actors interpret their world through a range of ideational elements including practices, symbols, frames, norms and discourses. ${ }^{41}$

In practice, the influence of ideational power in policy-making is complex. It can be exercised in a top-down or in bottom-up fashion taking into consideration struggles by actors at the top of the policy making hierarchy as well as those at the bottom through implementation of policies. ${ }^{42}$ The mechanisms of transmission of policy ideas have profound influence on actors, institutions, and instruments. Ideas may continue to remain reluctant to change over extended periods of time, shaping sectoral policies with consistent content as well as establishing and consolidating new and old processes. ${ }^{43}$ Hajer underscores role and structure of knowledge-communities in policy formulation. Discourse communities share some common level of understanding of a problem, its definition and its causes, including disagreements. ${ }^{44}$ These knowledge networks have also been conceptualized as epistemic communities.

39 Martin Carstensen \& Vivien Schmidt, "Power through, over and in Ideas: Conceptualizing Ideational Power in Discursive Institutionalism", Journal of European Public Policy, Vol. 23, Issue 3 (2016).

40 Martin Carstensen and Vivien Schmidt, "Power through, over and in Ideas: Conceptualizing Ideational Power in Discursive Institutionalism", Journal of European Public Policy, Vol. 23, Issue 3 (2016).

41 David Howard. 2009. "Power, Discourse, and Policy: Articulating a Hegemony Approach to Critical Policy Studies", Critical Policy Studies, Vol. 3 (3-4), (2009) pp. 309-355.

42 Collin Hay \& Rosamond Ben, "Globalization, European Integration and the Discursive Construction of Economic Imperatives", Journal of European Public Policy, Vol. 9 (2), (2002), pp.147-167.

43 Micheal Howlett and M. Ramesh, Studying Public Policy: Policy Cycles and Policy Subsystems, second edition. Oxford University Press Canada, 2003.

44 Maarten Hajer, "Discourse Coalitions and the Institutionalization of Practice: The Case of Acid Rain In Britain", Forester, Fischer and Forester (1993), pp. 4347. 
Haas defines epistemic community as "a network of professionals with recognized expertise and competence in a particular domain and an authoritative claim to policy-relevant knowledge within that domain or issue-area". ${ }^{45}$ Schulman provides a typology of ideas organized within communities, based on whether there is a consensus or not. ${ }^{46}$ Howlett and Ramesh have developed a matrix with four different dimensions: hegemonic, contested, fractious and chaotic communities. ${ }^{47}$ For example, a fractious community likely occurs where one idea is dominant but faces challenges from less popular but equally compelling set of ideas.

The policy-making process in the extractive sector in general mirrors a fractious discourse community. Extractive-led development frameworks in Africa continue to experience increasing patterns of contestations, stability and flux. There is extensive scholarship on varied mining regimes operating within the continent. In fact, the idea that natural resource inheritances should fuel faster and more equitable economic growth is hardly new. ${ }^{48}$ Reform efforts are at the centre of wider policy debates over the role of natural resource governance and economic development in the continent. ${ }^{49}$ Most scholars point at external influences - diffusion of western norms, rules, procedures as well as leverage of transnational actors on policy design and implementation in the minerals sector. ${ }^{50}$ As a deep core idea, reform efforts are underpinned by "free-mining", an ideology that guided the formulation of mining regimes in North America and Britain during the 19th century. ${ }^{51}$

45 Peter Haas, "Introduction: Epistemic Communities and International Policy Coordination", International Organization, Vol. 46, No. 1 (1992), p. 4, pp. 1-36.

46 Paul Schulman, "Non-Incremental Policy Making: Notes toward an Alternative", American Political Science Review, 69 (1975), pp. 1354-1370.

47 MichealHowlett \& M. Ramesh, Studying Public Policy: Policy Cycles and Policy Subsystems, Second Edition (Oxford University Press Canada, 2003).

48 Chris Robert, "The Other Resource Curse: Extractives as Development Panacea", Cambridge Review of International Affairs, Vol. 28, No. 2 (2015), pp. 283-307.

49 Hany Besada \& Philip Martin, "Mining Codes in Africa: Emergence of a 'Fourth' Generation?" Cambridge Journal of International Affairs, 28: 2 (2015), pp. 263-282.

50 Bonnie Campbell, Mining in Africa: Regulation and Development (Pluto Press, New York, 2009).

51 Bonnie Campbell, "Revisiting the Reform Process of African Mining Regimes", Canadian Journal of Development Studies/Revue canadienne d'études du développement, 30:1-2, (2010), pp. 197-217. 
The doctrine prioritizes mining rights over all other development uses of land, and bestows preferential treatment to mining companies over all other actors. ${ }^{52}$ Free mining laid down the ideological foundation for a package of neoliberal structural reforms that were conditioned on African countries for accessing development financing from international financial institutions, in particular the World Bank and the International Monetary Fund (IMF). The most significant reforms took place immediately after the oil crisis of the 1980s, preceding a post-colonial era where many African countries adopted a nationalistic state-led approach in developing their mining sector. ${ }^{53}$ Through its influential strategy for mining in Africa adopted in 1992, the World Bank mainstreamed free-market, private sector led approach to mining across the continent. ${ }^{54}$ The strategy framed the central challenge to Africa's mining sector as a supply-side problem - the lack of investment, which indebted mineral-rich countries were unable to provide in a sustainable manner for the development of the sector. Consequently, the report stated that future development of the industry in Africa would depend on attracting new high-risk capital from foreign mining companies.

Since then, mining reforms have evolved, albeit incrementally in the region. Taking the state as its focus, Campbell identifies three successive generations of liberalization reforms in the extractive sector in Africa. ${ }^{55}$ The first generation, illustrated by Ghana took place in the 1980s and was underpinned by the stringent withdrawal of the state from the sector to attract private investors. The second generation, exemplified by Guinea, took place in mid-1990s and was underpinned by the limited application of state authority, in specific areas like the protection of the environment. The third generation reflected the recognition that the state has a role to play in areas of regulation but limited to facilitation and secondary to the "ownership and operator" role of the mining companies. ${ }^{56}$

52 Bonnie Campbell, Regulating Mining in Africa: For Whose Benefit, Discussion Paper 26 (Upsala: Nordiska Afrikainstitutet, 2004).

53 Hany Besada \& Philip Martin, "Mining Codes in Africa: Emergence of a 'Fourth' Generation?" Cambridge Journal of International Affairs, 28:2 (2015), pp. 263282.

54 World Bank, Strategy for African Mining, World Bank Technical Paper No. 181 (Washington, 1992).

55 Bonnie Campbell, Regulating Mining in Africa: For Whose Benefit, Discussion Paper 26 (Uppsala: Nordiska Afrikainstitutet, 2004).

56 Bonnie Campbell, Regulating Mining in Africa: For Whose Benefit,' Discussion Paper 26 (Upsala: Nordiska Afrikainstitutet, 2004). 
Subsequent studies have built on the generation-based typology. Based on their procedural focus, Besada and Martin have qualified a new wave of private and transnational regimes focusing on governance as an emerging fourth generation of policy regimes in the mining sector. ${ }^{57}$ African countries remain central to the emerging governance innovations, including corporate social responsibility, Kimberly Process Certification Scheme (KPCS), Publish What You Pay (PWYP) and the Extractive Industry Transparency Initiative (EITI), and the US Dodd Frank law. Added to the mixture of externally driven regimes, Besada and Martin (2015) lumped them together with African owned frameworks. ${ }^{58}$ The paper however noted that the AMV adopted in 2009, by African Heads of States is the most important continental initiative on mining.

The generation-based typology, as captured in the above studies, reveals a fundamental methodological and substantive weakness. It is non-hierarchical in the way it frames policy change as such fails to distinguish between, change that is substantive and that which is merely procedural. The time-series typology assumes rather than explains the ideational foundation of change through the power in ideas. ${ }^{59}$ In fact, it is the deeper level of ideas that frames the policy options including instruments that are normatively possible.

Consequently, the generation-based typology erroneously lumps different degrees of change, including core normative ideas and implementation mechanisms together. The studies are, therefore, limited in capturing finer elements and time-relevant dimensions of ideas and how they have shaped mineral regimes in Africa. For example, besides the aforementioned first generation of regimes, there have been no apparent marked changes in the deep core ideas of the subsequent generations of regimes identified, until the adoption of the AMV. All the precedent generations of regimes are founded on a deep-seated idea of primarily capturing rents from minerals resources before building the necessary linkages and diversification for the broad-based

57 Hany Besada \& Philip Martin, "Mining Codes in Africa: Emergence of a 'Fourth' Generation?" Cambridge Journal of International Affairs, 28: 2 (2015), pp. 263-282.

58 Ibid.

59 Martin Carstensen and Vivien Schmidt, "Power through, over and in Ideas: Conceptualizing Ideational Power in Discursive Institutionalism", Journal of European Public Policy, Vol. 23, Issue 3 (2016), p. 362. 
development of the sector. ${ }^{60}$ The neoliberal and free-mining doctrine continues to be an enduring idea across different generations of regimes. The change therefore underscored by the second, third and fourth generation of regimes is limited to mechanisms and instruments rather than substance of ideas, consistent with the Peter Hall'sfirst and second order change mentioned above. ${ }^{61}$

The appropriation of AMV in Africa by businesses and civil society organizations remains work in progress. A general critique is its focus on resurrecting the developmental state ${ }^{62}$ - greater state involvement, activist industrial policy-making, and resource nationalism. There remain concerns about the ability of Africa to leverage its regional governance regimes in ways that transform the continent from norm-taker to normsetter. ${ }^{63}$ Leveraging the transformative potential of Africa's abundant minerals resources as encapsulated in the AMV has recently been labelled another resource curse. ${ }^{64}$ The proposition is that, geological endowment alone is not panacea for economic development, industrialization and poverty alleviation. He underscores perceived contradictions inherent in the AMV and the unintended, unpredictable and unwelcome consequences of misreading the complex nature of the extractive industry in Africa. However, despite implementation challenges, Robert's conclusion that AMV remains fixated on maximizing minerals endowment of the continent is inaccurate.

The AMV, in fact, is a dynamic and multidimensional framework, with an ideational foundation based on optimizing the value of Africa's

60 Economic Commission for Africa, Minerals and Africa's Development: The International Study Group Report (Addis Ababa, 2011).

61 Peter Hall, "Policy Paradigms, Social Learning and the State: The Case of Economic Policy Making in Britain", Comparative Politics, 25, 3 (1993), pp. 275-96.

62 Hany Besada \& Philip Martin, "Mining Codes in Africa: Emergence of a 'Fourth' Generation?", Cambridge Journal of International Affairs, 28:2 (2015), pp. 263282; Timothy Shaw (2015). "Public Diplomacy for Developmental States: Implementing the African Mining Vision". In George Kararach, Hany Besada, Timothy Shaw (eds), Development in Africa: Refocusing the Lens after the Millennium Development Goals (Policy Press, Bristol, 2015).

63 Economic Commission for Africa, Minerals and Africa's Development: The International Study Group Report (Addis Ababa, 2011); William Brown, "A Question of Agency: Africa in International Politics", Third World Quaterly, Vol. 33, No. 10 (2012), pp. 1899-908; William Brown and Sophie Harman, African Agency and International Relations (Abingdon: Routledge, 2013).

64 Chris Robert, "The Other Resource Curse: Extractives as Development Panacea". Cambridge Review of International Affairs, Vol. 28, No. 2 (2015), pp. 283-307. 
rich-mineral resources for broad-based development rather than maximizing rents accruing from their exploitation (Akong, forthcoming). The continental owned strategy extends beyond capitalizing on Africa's comparative advantage. It aims to create internationally competitive mining economies in the continent, through integrating markets for mineral products from the local, national and regional levels - catalysing the emergence of viable regional value chains as well as inserting economies into the higher rungs of global minerals value chains.

The emergence of the AMV is set against outcomes of neoliberal reforms, which so far remain mixed and widely debated. ${ }^{65}$ While successful in attracting increased foreign investment, natural resource exploitation in Africa has been labelled a curse. ${ }^{66}$ African governments, communities and citizens have questioned the development benefits of mining reforms. ${ }^{67}$ Neoliberal regulations in the sector are blamed for maximizing benefits for privately owned companies and few elites, excluding a large majority of the population from the sharing of benefits of their mineral wealth. ${ }^{68}$ The externally driven reforms are perceived as lacking legitimacy and democratic accountability. ${ }^{69}$

The United Nations Research Institute for Social Development argues that the pressure of aligning macroeconomic objectives with

65 Paul Collier and Anthony Venables. 2011. Plundered Nations? Successes and Failures in Natural Resource Extraction (Palgrave, New York, 2011).

66 Jeffrey Sachs and Andrew Warner, "Natural Resources and Economic Development: The Curse of Natural Resources", European Economic Review, 45 (2001), pp. 827-838; Cherily Gray and Daniel Kaufmann, "Corruption and Development", Finance and Development, Volume 35, Number 1 (1998); Stephen Haber and Victor Menaldo, "Do Natural Resources Fuel Authoritarianism? A Reappraisal of the Resource Curse", American Political Science Review (2011); Anthony Venables, "Using Natural Resources for Development: Why Has It Proven So Difficult?”, J. Econ. Perpect, 30(1), (2016), pp. 161-184.

67 Nathan Jensen and Leonard Wantchekon, "Resource Wealth and Political Regimes in Africa", Comparative Political Studies, Vol. 37 No. 7 (2004), pp. 816841; Timothy Shaw, "Public Diplomacy for Developmental States: Implementing the African Mining Vision". In George Kararach, HanyBesada, Timothy Shaw (eds), Development in Africa: Refocusing the Lens after the Millennium Development Goals (Policy Press, Bristol, 2015).

68 Bonnie Campbell, Mining in Africa: Regulation and Development (Pluto Press, New York, 2009).

69 Hany Besada, \& Philip Martin, "Mining Codes in Africa: Emergence of a 'Fourth' Generation?" Cambridge Journal of International Affairs, 28:2 (2015), pp. 263282. 
the demands of attracting foreign investment encourages governments to insulate economic decisions and policy-making from democratic scrutiny. ${ }^{70}$ The lack of capacity of African states to monitor and enforce natural resource governance in addition to the growing expectation and reality-gap of mining-based development has prompted calls for stronger natural resource strategies. ${ }^{71}$ The unequal relationships between African countries and large multinational and powerful financial institutions that resulted from the reforms have also been cited as a failed outcome. Citing a World Bank report, one recent study observes that "every country that borrowed from the Bank did worse the more it depended on extractive resource". ${ }^{72}$ A review of the impact of the World Bank-supported reforms concludes that the neo-liberal ideology is inconsistent with building a set of strong institutions to drive structural transformation in African economies. ${ }^{73}$

The birth of the AMV in 2009 also coincided with the emergence of varieties of capitalism in development thinking. ${ }^{74}$ In addition to the traditional models of capitalism, Nölke and Vliegenthart conceptualize another variant of capitalism - the state-permeated market economies -as typical for large emerging economies. ${ }^{75}$ They argue that the countries practising this new form of capitalism are deeply enmeshed in the international trading system and global production networks. Owing to the large size of their domestic markets, governments of emerging economies have a good negotiation position towards foreign investors and governments and are able to practise a selective opening of the economy.

70 United Nations Research Institute for Social Development, Growth, Macroeconomic Policies and Structural Change, UNRISD Flagship Report, (Geneva, 2000).

71 Hany Besada \& Philip Martin, "Mining Codes in Africa: Emergence of a 'Fourth' Generation?" Cambridge Journal of International Affairs, 28:2 (2015), pp. 263282.

72 Tom Burgis, The Looting Machine: Warlords, Oligarchs, Corporations, Smugglers and the Theft of Africa's Wealth (New York Press, 2015), p. 99.

73 Economic Commission for Africa, Economic Report on Africa: Governing Development in Africa - The Role of the Sate in Economic Transformation (Addis Ababa, 2011).

74 Andrea Goldstein, Multinational Companies from Emerging Economies (Palgrave Macmillan, London, 2007).

75 Andreas Nölke and Vliegenthart Arjan, "Enlarging the Varieties of Capitalism: The Emergence of Dependent Market Economies in East Central Europe," World Politics, Vol. 61, No. 4 (2009), pp. 670-702. 
The rise of several of these large emerging economies, collectively labelled as the BRICS, and enhanced by the 2008 global financial crisis arguably ranks among the most important contemporary structural changes in the global political economy. The emergence of BRICS was believed to open up the policy space for new thinking about alternative forms of capitalism, which are more adaptable to a country's own realities - combining state-led and market interventions. ${ }^{76}$ In addition, China's insatiable demand for commodities was believed to stay long enough in to continuously lead to rising prices for Africa's minerals. ${ }^{77}$ African agency was underscored as a determined response by the continent's developmental states to the gains rather than costs of the discovery of Africa's potential by the BRICS, especially China. ${ }^{78}$

The outcomes of substantive and enduring reforms of the extractive sector in Africa remain an open question. The disillusionment over the Washington consensus of neoliberal reforms has yet to yield alternative policy frameworks even within the context of post-Washington consensus, where finding the right balance between state and markets is increasingly recognized. Resistance to change has been linked to national and international structures of power that favour corporations as well as national elites that align behind them. ${ }^{79}$ Ideas and discourses are just a part of the elements behind policy change. Actors often act without having ideas about what they are doing, let alone talking about it, until after they actually do it. ${ }^{80}$

Policy change is therefore dynamic, complex and a complicated process with ideas playing an important role. The mode of ideational change in the extractive industry may take several forms: multiple streams, advocacy coalition, policy diffusion and punctuated

76 The rise of state capitalism, in The Economist, 21 January 2012.

77 Economic Commission for Africa, Minerals and Africa's Development: The International Study Group Report (Addis Ababa, 2011).

78 Timothy Shaw, "Public Diplomacy for Developmental States: Implementing the African Mining Vision". In George Kararach, Hany Besada, Timothy Shaw (eds), Development in Africa: Refocusing the Lens after the Millennium Development Goals (Policy Press, Bristol, 2015).

89 Eduardo Canel, Uwafiokun Idemudia and Liisa L. North Canela, "Rethinking Extractive Industry: Regulation, Dispossession, and Emerging Claims", Canadian Journal of Development Studies/Revue canadienne d'études du développement, Vol. 30, No. 1-2 (2010), pp. 5-25.

80 Vivien Schmidt, "Discursive Institutionalism: The Explanatory Power of Ideas and Discourse", The Annual Review of Political Science, 11 (2008), pp. 303-26. 
equilibrium. ${ }^{81}$ According to the multiple streams theory, advocates and experts in the policy stream have ideas about policies and monitor the problem stream for a condition amiable to their solution in what has been labelled "problem surfing". ${ }^{82}$ The advocacy coalition framework focuses on learning and policy change within a policy subsystem, taking into consideration both internal and external shocks to the subsystem. ${ }^{83}$ Policy diffusion tracks how similar policy innovations are adopted across countries and sectors. ${ }^{84}$ Originally introduced by Baumgartner and Jones, the punctuated equilibrium focuses on two facets of policymaking, long periods of stability and periods of long-term change. ${ }^{85}$

All theories have their own weaknesses and room always exists for improvement and better policy application. Therefore, any attempts to find one simple causal policy mechanism for change applicable to every country, sector, context and minerals will invariably fail in contributing to informed decision-making.In examining motivations behind policy interventions, Stevens et al argue that the focus of prevailing policy ideas on better management is based on a patently wrong assumption that the same type of sector management is suitable for every country and mineral. ${ }^{86}$

There appears to be evolution in the literature of the resource curse thesis. Increasingly the criticisms of natural resource led development, is shifting from the classic resource curse, amenable to one-size-fits-all policy interventions to a softer but sophisticated critique of the ideational foundation of development prescriptions. This affirms why Africa's place, at the centre of transnational governance innovations in

81 Micheal Howlett and M. Ramesh, Studying Public Policy: Policy Cycles and Policy Subsystems, Second edition. Oxford University Press Canada, 2003); John Kingdon, Agendas, Alternatives and Public Policies (University of Michigan, 1984); Paul Sabatier, "An Advocacy Coalition Framework of Policy Change and the Role of Policy-Oriented Learning", Policy Sciences, 21, 2/3 (1988), pp. 129-68.

82 Jessica Boscarino, "Surfing for Problems: Advocacy Group Strategy in U.S. Forestry Policy", Policy Studies Journal, Vol. 37, No. 3 (2009), pp. 415-34.

83 Paul Sabatier, "An Advocacy Coalition Framework of Policy Change and the Role of Policy-Oriented Learning", Policy Sciences, 21, 2/3 (1988), pp. 129-68.

84 Frances Berry and William Berry. 2007. "Innovation and Diffusion Models in Policy Research". In Paul Sabatier, Theories of the Policy Process, eds, pp. 223-60 (Westview Press, Boulder, 2007).

85 Frank Baumgartner and Bryan Jones, "Agenda Dynamics and Policy Subsystems", The Journal of Politics, Vol. 53, No. 4 (1991), pp. 1044-74.

86 Paul Stevens, GladaLahn and Jaakko Kooroshy, The Resource Curse Revisited, (Catham House, London, 2015). 
the extractive sector remains a source of renewed optimism. ${ }^{87}$ Future work on how Africa's ideas effectively create agency will provide better policy guidance for positioning the continent in the global economy. In fact, as Brown underscores: Africa should be viewed as actor, not just acted upon, and historical agent not just history's recipient. ${ }^{88}$

\section{THE AFRICA MINING VISION}

The AMV is as old as mining and development in post-independent Africa. The motivations behind the Vision remain diverse, including economic, social and political. Central to the AMV is the recurrent challenge of structural transformation of economies. ${ }^{89}$ Decades of mineral exploitation in various countries, is yet to translate into lasting development outcomes. ${ }^{90}$ Even after several reforms in the sector, mostly driven by external institutions, the paradox of plenty affects policy interventions in the sectorsuch that vast mineral exploitation projects continue in enclave manner, side by side with extreme poverty. For example, Antonio has underscored coordination gaps, which have limited mining investment from leveraging linkages with transformative impacts on other critical sectors. ${ }^{91}$

The insular and failed policies reflect a much deeper set of complex challenges of the mining industry in Africa. Shaped by historical and political economy factors, the deficiencies remain a central feature and binding constraint to transform the sector. Largely a colonial creation, African countries continue to occupy a marginal position, at the lowest rung of the global value chain. African countries are yet to take full

87 Economic Commission for Africa, Africa Governance Report II (Addis Ababa, 2009); Kobena Hanson, George Kararach, and Timothy Shaw, Rethinking Development Challenges for Public Policy: Insights from Contemporary Africa (eds) (Palgrave Macmillan, London, 2012).

88 William Brown, "A Question of Agency: Africa in International Politics", Third World Quaterly, Vol. 33, No. 10 (2012), pp. 1899-908.

89 Economic Commission for Africa, Minerals and Africa's Development: The International Study Group Report on Africa's Minerals Regimes (Addis Ababa, 2011).

90 Alastair Fraser and John Lungu, For Whom the Windfalls: Winners and Losers in the Privatisation of Zambia's Copper Mines (Southern African Regional Poverty Network, 2006).

91 Pedro Antonio, "The Country Mining Vision: Towards a New Deal", Mineral Economics (2015), pp. 1-8. 
advantage of their abundant mineral endowment to drive their industrialization and structural transformation of economies. ${ }^{92}$ African economies remain primary suppliers of key minerals to drive industrialization for other economies, outside the continent.

The priorities of the AMV are therefore a product of longstanding aspirations of African governments to chart an alternative development path that is owned by countries. The framework builds on previous policies and processes at the continental level. For examples, the 1979 Monrovia Declaration committed African countries to achieve selfreliance through cooperation in areas of natural resources management including extraction. The Lagos Plan of Action for the Economic Development of Africa adopted in 1980 by the Organization of African Unity (now AU) provided concrete actions to the Declaration. The Plan proposed an alternative narrative to the structural adjustment programmes imposed by the Bretton Wood institutions as well as highlighted the vulnerability of African economies to worldwide economic shocks including the oil price shocks of 1973.

The changing business society relations over the last decade have influenced the design of the AMV. The increased scrutiny of the activities of transnational companies has further raised the negative profile of the industry in Africa and the need for more forward looking approaches. The strengthening of globalization during the 1990s came with the growth of new modes of governance, which are more voluntary and inclusive.

The timing of AMV coincided with the spectacular emergence of China as an economic power of global reach, creating space unlike before for African alternative development approaches. China's outsize influence as the world's greatest consumer of metals, introduced a strong element of competition as well as expectations of sustained demand and high prices for Africa's commodities. The China-led supercycle of upward rising commodity prices, strengthens the bargaining power of African countries as owners of highly demanded commodities over mining companies. During the period of the boom, African countries seized the leadership opportunity presented to organize stakeholders for lasting solutions towards improving governance for the sector. The African Union (AU), Africa Development

92 Economic Commission for Africa, Making the Most of Africa's Commodities: Industrializing for Growth, Jobs and Economic Transformation (Addis Ababa, 2013). 
Bank (AfDB), and United Nations Economic Commission for Africa (UNECA) adopted a number of declarations and resolutions which led to the organization of the "Big Table", a multistakeholder forum held in 2007, followed by the first conference of the AU Ministers of Mines held in 2008.

An International Study Group (ISG) established by UNECA and the AUC in 2007 brought together globally renowned experts from private, public and civil society sectors. The ISG reviewed Africa's mining regimes and produced a comprehensive report that laid the foundation for the AMV. The ISG report asserted that the structural transformation of African economies is "an essential component of any long term strategy to ensure the attainment of the Millennium Development Goals (MDGs) ..., eradicate poverty and underpin sustainable growth and development", and that this requires "a strategy ... rooted in the utilization of Africa's significant resource assets. ${ }^{93}$

The AMV responds to the ISG report as it embodies a set of core ideas, principles and instruments for structural transformation in Africa's mining sector. Adopted by African Heads of States in 2009, the Vision marks, for the first time, the articulation of Africa's agency and resolve to shift from norm-taker to norm-setter. It represents a paradigm shift, away from the entrenched focus on maximizing revenues from export of commodities in their raw forms, towards harnessing mineral resources for broad-based development. As a visible collective expression of developmental state ambition by Africa, the vision calls on member states to align their minerals policies strongly with industrial, trade and science, as well as their technology and innovation policies.

The continental framework seeks to create a "transparent, equitable and optimal exploitation of Africa's mineral resources to underpin broad-based sustainable growth and socio-economic development". ${ }^{94}$ The strategy attempts not only to address the sector's isolation from mainstream social and economic activities but also create win-win outcomes for all stakeholders. The Vision's key tenets are to integrate the economic, social and environmental pillars of sustainable development, including optimizing knowledge and benefits of finite

93 Economic Commission for Africa, Minerals and Africa's Development: The International Study Group Report on Africa's Minerals Regime, (Addis Ababa, 2011), p. 2.

94 African Union, The Africa Mining Vision (Addis Ababa, 2009), p. 1. 
mineral resources at all levels of mining and for all minerals; harnessing the potential of small scale mining to improve livelihoods and integration into the rural and national economy; fostering sustainable development principles based on environmentally and socially responsible mining, which is safe and includes communities and all other stakeholders; building human and institutional capacities towards a knowledge economy that supports innovation, research and development; developing a diversified and globally competitive African mineral industry which contributes to broad economic and social growth through the creation of economic linkages; fostering a transparent and accountable mineral sector in which resource rents are optimized and used to promote broad economic and social development; and promoting good governance of the mineral sector in which communities and citizens participate in mineral assets and in which there is equity in the distribution of benefits. ${ }^{95}$

The main instruments of the AMV include its Action Plan adopted in 2011 as well as its guidebook for undertaking the Country Mining Vision (CMV) adopted in 2014. The action plan comprises nine programme clusters of activities constructed around the key tenets. The CMV operations manual developed by the African Minerals Development Centre (AMDC) provides a practical step-by step guide, setting out how countries can apply the AMV in their own context. The CMV facilitates the articulation of a vision, including the emergence of a new social contract for the sector that extends beyond political and commodity cycles. The CMV remains the main tool used by AMDC and its implementing partners to support countries.

As a bold vision, the AMV aims to focus discussions on the role of minerals in African countries development. The CMV therefore provides an institutional process for a not-business-as-usual approach broadening the dialogue with stakeholders from the traditional entry point of Ministry of Mines to include Ministry of Industry, Trade, Education and Research as well as private sector and civil society actors. The CMV creates a policy space for the kind of conversation that goes beyond optimizing revenue potentials of mining through the usual recipe of measures such as improvements of legal and regulatory frameworks, tweaking the mineral fiscal regime or offering investors a

95 African Union, The Africa Mining Vision (Addis Ababa, 2009), p. 1. 
predictable and stable business environment. It opens space for far deeper and fundamental structural shift, which calls for a new dispensation and paradigm change. ${ }^{96}$

The AMV regime includes the Vision, its Action Plan, CMV its domesticating tool, and its institutional partners including the Africa Union Member States, Regional Economic Communities (RECs), African Union Commission, African Development Bank, United Nations Economic Commission for Africa, and the Africa Minerals Development Centre.

\section{TOWARDS A DYNAMIC CONCEPTUAL FRAMEWORK}

To frame policy change in the extractive sector in Africa, we adapt John Kingdon's multivariate and crisis-driven model of agenda setting. ${ }^{97}$ Three key variables interact to turn ideas into policy change: problems, policy and politics streams (see Figure 1). The choice of the framework

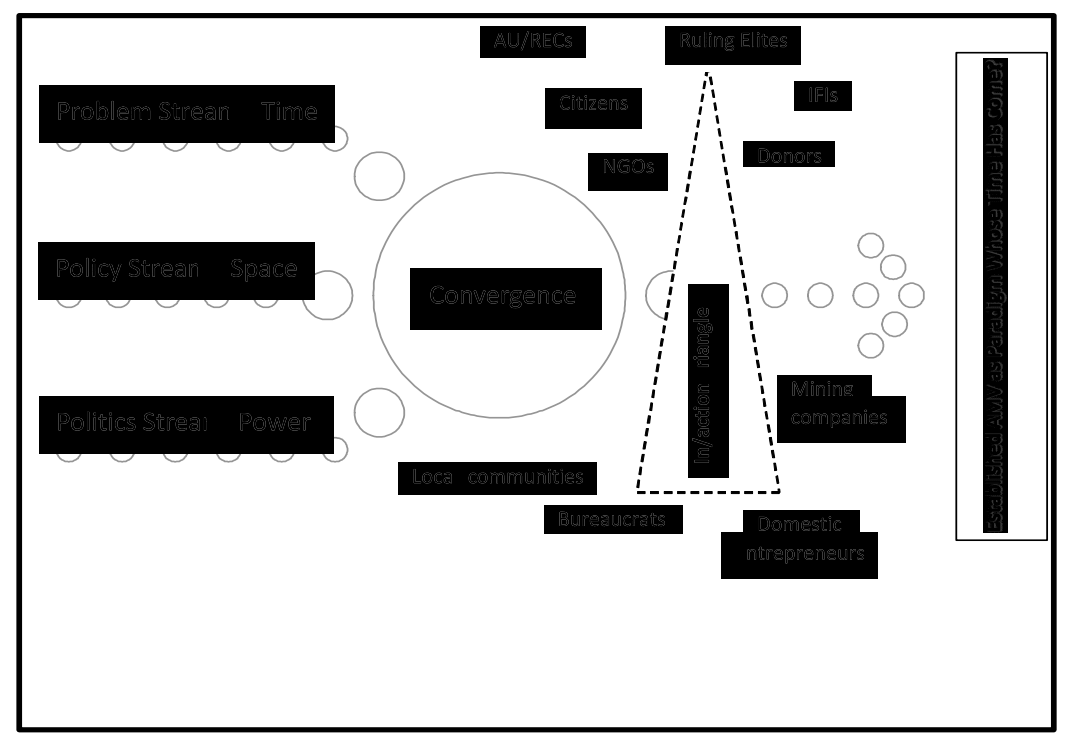

Figure 1. An Innovative Dynamic Framework for Conceptualizing the AMV Paradigm Shift

96 Pedro Antonio, "The Country Mining Vision: Towards a New Deal", Mineral Economics (2015), pp. 1-8

97 John Kingdon, Agendas, Alternatives and Public Policies (University of Michigan 1984). 
is useful because it can be extended to include all stages of policy process, including policy implementation. A growing number of studies are adapting the framework beyond agenda setting. ${ }^{98}$ In fact, Ness and Mistretta (2009) notes that entrepreneurs actively seek to merge streams in order to ensure that their preferred policy design is implemented. ${ }^{99}$

Adapting the multiple stream framework, we examine volatility as the key problem facing extractive-led development agenda. Industrialization is analysed as sustainable policy option to manage volatility as well as catalyse broad-based transformation of the structures of mineral rich economies. The political stream consists of factors such as contextual changes including institutions, interests and actors realignment.

According to Kingdon (1984), the three streams operate separately and pursue different paths, which may be less overlapping, until specific points in time or policy windows where their paths can interact mutually. ${ }^{100}$ Policy windows could be seized to establish an already existing paradigm or bring about a paradigm shift. Kingdon further attributed windows opening to two sources: political and problem streams.

The proposed framework is an innovation to the multiple stream concept by integrating key elements of political economy into a crosscutting stream. The political economy triangle extends the multiple stream framework to capture the dimensions of interests constellations and their interactions with the power frames of the ideas. It acts like prism filtering the ideas in the politics, problem and policy streams in ways that may resist or catalyse change. Basically it involves the mutual political and economic relations, which shape the behaviour of actors, institutions, sector and society. ${ }^{101}$ It includes a triangle of incentives of ruling elites, bureaucrats and business elites to work towards the

98 Mathew Nowlin, "Theories of the Policy Process: State of the Research and Emerging Trends", The Policy Studies Journal, Vol. 39, No. S1 (2011), pp. 4160.

99 Eric Ness and Molly Mistretta, "Policy Adoption in North Carolina and Tennessee: A Comparative Case Study of Lottery Beneficiaries", The Review of Higher Education, Vol. 32, No. 4 (2009), pp. 489-514.

100 John Kingdon, Agendas, Alternatives and Public Policies (University of Michigan, 1984).

101 Guide for Political Economy Analysis in the Mining/Extractives Sector (Governance Social Development Humanitarian Conflict, 2013). 
implementation of the AMV principle of a transparent, equitable and optimal exploitation of mineral resources to underpin broad-based sustainable growth and socio-economic development. It also takes into consideration the dynamics within local communities in mineral rich countries.

Meanwhile, from a geometric perspective, we further incorporate multidimensional concepts of time, space and power to capture the full transformative potentials of all minerals. The dimensions are based on a typology of the ideas underpinning mining and development policy, which could be organized into temporal, spatial and capability theories. ${ }^{102}$ Time captures volatility, which reflects cyclical movement in prices in the commodity markets. Space reflects industrialization, which captures the spatial nature of commodity-led development strategies. The space dimension captures opportunities for value addition, linkages and diversification. It examines the potentials of upgrading within regional and global value chains. Power captures political opportunities for collective actions, including regional integration, global dynamics and emerging development priorities.

The advantage of the crisis-driven model is that it effectively incorporates key institutional factors such as public mood, which Kingdon (1984) labelled as essential randomness. ${ }^{103}$ By capturing the dimension of interests, the framework systematically analyses the dynamics of extractive-led development in Africa including the distribution and contestation of power at the top and bottom of the hierarchy of policy making and implementation. The addition of the interest networks further corrects for the determinism inherent in the multiple streams model, which assumes policy change to be straightforward and automatic, when windows of opportunities open. ${ }^{104}$

We affirm that the dimension of the entrenched role of actors provides a robust model for analysing the potential of the AMV in transforming minerals sector governance in Africa. This approach is consistent with contemporary policy scholarship, which explains paradigmatic change in terms of dynamics within epistemic

102 Charles Akong, Framing Matters: A Transformative Taxonomy for Africa's Minerals (forthcoming).

103 John Kingdon, Agendas, Alternatives and Public Policies (University of Michigan 1984).

104 Ibid. 
communities and interest networks. ${ }^{105}$ Policy change therefore is a configuration of outcomes ranging from slow incremental to rapid paradigmatic policy change. ${ }^{106}$

\section{AN IDEA WHOSE TIME HAS COME?}

This section adopts the adapted multiple streams and interests-based models presented above, to explore the challenges and opportunities for establishing AMV as an enduring paradigm shift. The analysis will examine the AMV along the problem stream, policy stream and politics stream. It also captures the dimension of political economy to account for vested interests in the way of implementation.

\subsection{Problem Stream}

Sharp and continuous decline in commodity prices started in 2012 and persists. The situation is complex, uncertain and ambiguous. Commodities have significantly fallen across the board albeit at varying degrees. Commodity price indexes have all fallen with the World Bank Metal Price Index ending 2015 at 50 per cent lower than its 2011 highs (World Bank, 2015). Price formation and movements determined both by market fundamentals as well as non-market forces including political risks remain difficult to predict.

The collapsing prices of metals and minerals remain a major problem to commodity dependent countries. African mineral exporters are price takers with most of them exporting commodities in their raw forms. With limited influence on demand side drivers of prices, African countries have been highly vulnerable to global price movements, driven largely by dwindling appetite for commodities from China, which consumes almost 50 per cent of world metals. ${ }^{107}$ With no sign of any emerging economy picking up the slack, volatility remains very

105 George Hoberg, "Putting Ideas in their Place: A Response to Learning and Change in the British Columbia Forest Policy Sector", Canadian Journal of Political Science, Vol. 29(1) (1996), pp. 135-144.

106 Michel Howlett and M. Ramesh, Studying Public Policy: Policy Cycles and Policy Subsystems, Second edition (Oxford University Press, 2003).

107 United Nations Conference on Trade and Development (UNCTAD), Excessive Commodity Price Volatility: Macroeconomic Effects on Growth and Policy, (Geneva, 2012). 
significant and even higher when compared to the last century. ${ }^{108}$

Rapid price movements and excessive resource-dependency together have imposed severe macroeconomic pains. Currencies supported by commodities are under strain, with Zambian Kwacha weakening rapidly following significant slide in copper prices as well as Angola, which devalued its Kwaza twice in 2015 by a total of 22 per cent. ${ }^{109}$ According to one estimate, Africa oil exporting countries are losing over US $\$ 63$ billion for every 30 per cent decline in oil prices. ${ }^{110}$ The Nigerian government has taken measures to restrict growing import bill in order to save the country's dwindling reserves. In fact, Africa's growth projection by the IMF remains downbeat: even though finishing 2015 at less than four per cent, the continent continues to perform above the global average. ${ }^{111}$

The industry is no stranger to the familiar patterns of painful supercorrections following super cycles, a once-in-generation period of high prices that started in the 2000s. Investors have responded with spending cuts and layoffs by some of the world's biggest mining companies in Africa. Drill activity around the world dropped, with Africa's share of drilling dropping slightly from 15 per cent in July 2014 to 12 per cent in 2015. ${ }^{112}$ Broken down, the drill results announced for base metals dropped far much than those of precious metals, with six per cent in 2015 against 14 per cent in 2014 and for gold we have from 19 per cent in July 2014 to 15 per cent in July 2015. For the first time since 2009 , the market value of the global mining industry dropped below US\$1 trillion, compared to 2.5 trillion just over four years ago. ${ }^{113}$

The current crisis reveals structural weakness of the revenue-first model, which centres on maximizing collection of resource rents for investment in development activities after. In defending the rent

108 United Nations Conference on Trade and Development (UNCTAD), Excessive Commodity Price Volatility: Macroeconomic Effects on Growth and Policy (Geneva, 2012).

109 African Business, "What is the Impact of Low Oil Prices on African Economies?", 12 November 2015.

110 Zhenbo Hou, Jodie Keane, Jane Kennan and Dirk Willemte Velde, The Oil Price Shock of 2014: Drivers, Impacts and Policy Implications (Overseas Development Institute, London, 2015).

111 International Monetary Fund, Regional Economic Outlook: sub-Saharan Africa Navigating The Headwind (Washington D.C., 2015).

112 SNL Metals \& Mining, Monthly Industry Monitor, August 2015.

113 SNL Metals \& Mining, Monthly Industry Monitor, October, 2015. 
maximization model, the Natural Resource Governance Institute (NRGI) recently noted that in "every crisis there is a story of a government that has planned well in advance" to deal with it. ${ }^{114}$ Yet African countries seem to have done relatively well on this score. Resource rich Africa improved its tax take during the boom period, with resource rents jumping from 39 per cent in 2000-2003 to 43 per cent in 2010-2013. ${ }^{115}$ Tax levels are high with average corporate income tax rate in Africa, which applies to the mining sector approximating 32 per cent, higher than the world average. ${ }^{116}$

Nevertheless, this is just one side of much more complex story of extractive-led development in Africa. More revenue has not meant better spending and improved outcomes. The ideational foundation of the neoliberal mining regimes and their improved variants has not been solid enough to bring about fiscal transformation. ${ }^{117}$ Its deep core idea, which disproportionately privileges the interests of mining companies over that of governments and communities remains ill-adapted to inform effective policy design and implementation. Its procedural focus on efficiency and transparency rather than equity and fairness, means African countries are yet to mobilize optimal value from their mineral resources.

In 2010, mining companies net an aggregate profit of US\$110 billion, an increase of 156 per cent from the previous year. ${ }^{118}$ Mining companies' profits increased at four times the rate of government revenues between 2000 and 2011, when world gold prices jumped from US $\$ 300$ to US $\$ 1,600$ per ounce. ${ }^{119}$ As a consequence of the liberal fiscal policies accompanying privatization, virtually none of the resource

114 Natural Resource Governance Institute, “Why Weren't Governments Better Prepared for the Commodity Crash?", 3 July, 2015, p. 2.

115 African Development Bank, "Regional Development and Spatial Inclusion", Africa Economic Outlook (Abidjan, 2015), p. 64.

116 African Development Bank, AfDB, African Economic Report (Tunis, 2010).

117 Hany Besada \& Philip Martin, "Mining Codes in Africa: Emergence of a 'Fourth' Generation?", Cambridge Journal of International Affairs, 28:2 (2015), pp. 263-282; Bonnie Campbell, "Revisiting the Reform Process of African Mining Regimes", Canadian Journal of Development Studies/Revue canadienne d'études du développement, 30:1-2 (2010), pp. 197-217.

118 Economic Commission for Africa, Minerals and Africa's Development: The International Study Group Report on Africa's Minerals Regimes (Addis Ababa, 2011).

119 Africa Progress Panel, "Equity in Extractives Africa Progress Report 2013 Stewarding Africa's Natural Resources For All” (Geneva, 2013). 
rents accruing from copper mining in Zambia went to the government. That is, whereas copper mining had contributed an average of 45 per cent of government's revenues between 1965 and 1975, it made virtually no direct contribution to government revenues during the pre-financial crisis boom of 2002 to $2008 .^{120}$

Sub-optimal policy instruments further translate into weak administrative capacity. In fact, African countries have stuck with the low hanging fruits of taxation - production-based fixed royalties. According to a survey conducted by the African Development Bank, with the exception of South Africa, which imposed a profit-based royalty, all other African countries used ad-valorem royalty as of mid-2011. ${ }^{121}$ Furthermore, almost all royalty rates in Africa were fixed, with only a few exceptions. For example, in 2010 Burkina Faso instituted an advalorem royalty rate that was indexed to gold prices. Specifically, the minimum royalty rate is 3 per cent (ad-valorem), which increases to 4 per cent when gold prices are between USD1,000/ounce and USD1,300/ounce, and further to 5 per cent when prices go in excess of USD1, 300/ounce. ${ }^{122}$ Nonetheless, the average corporate income tax in Africa, which applies to the mining sector approximates 32 per cent, but given the lengthy tax exemption period granted to numerous mining companies, this profit-based tax rarely is a major source of revenue to most African countries. ${ }^{123}$

Inadequate attention to fairnessas a foundational idea continues to create asymmetry of power relations as well as gaps in fiscal regimes, exploited by mining companies to avoid taxes with damaging consequences on domestic resource mobilization. Rawls argues that acting unfairly is not so much about breaking a particular rule, but taking advantage of the loopholes or ambiguities in rules, insisting that rules be enforced to one's advantage when they should be suspended and acting contrary to the intended spirit of the law. ${ }^{124}$

120 Elvra Bova, "The Implications of Mine Ownership for the Management of the Boom: A Comparative Analysis of Zambia and Chile", Swiss National Center of Competence Research, Working Paper No. 2009/13 (Bern, 2009).

121 African Development Bank, Gold Mining in Africa: Maximizing Economic Returns for Countries (Tunis, 2013).

122 Dunn Loren Merrifield, "The Nigerian Cement Industry: Cement Industry Report", 11 September, 2014, p. 54.

123 African Development Bank, Royalty Rates in African Mining Revisited: Evidence from Gold (Tunis, 2012).

124 John Rawls, “Justice as Fairness”, The Philosophical Review, Vol. 67, No. 2 (1958). 
Mining companies increasingly are accused of violating the principle of fair play by accepting government's protection of their property rights to mine without paying their fair contribution to the functioning of state through taxes. While illicit financial leakages outside the mining sector are difficult to estimate, a clear relation exists between countries that are highly dependent on mining and incidence illicit financial outflows. The AU/ECA High Level Panel reported extensive underreporting of quantity and quality of mineral resources extracted for export, robbing African people of their benefits. The Report estimates that over US $\$ 50$ billion leave the continent yearly, including through aggressive tax avoidance and evasion schemes as well as abuses of market power. ${ }^{125}$ This is greater than the overall external development assistance to Africa. A recent study of selected commodity-rich countries, including African,shows that governments are losing almost 67 per cent of their minerals export in illegal trade mis-invoicing practices. ${ }^{126}$

Nevertheless, the reliance on internally generated resources rather than aid, remains crucial for diversifying and transforming mineral-rich African economies. ${ }^{127}$ By collecting more taxes, governments will develop their own governance capacity, including spending even better on critical infrastructure for linking mining to the broader economy. "Taxation reflects the intrinsic legitimacy of the state, based on the effectiveness of institutions manifested in actual compliance. ${ }^{128}$ An effective system including capacity for collecting optimal revenues from natural resources would solidify the often weak social contract between governments and citizens for equitable delivery of benefits from mining.

In fact, against the depressed market conditions, there continues to exist considerable scope for mineral-rich African countries to review current royalty rates. While there are certainly fears of further scaring

125 Economic Commission for Africa, Track It! Stop It! Get It!: Report of the High Level Panel on Illicit Financial (Addis Ababa, 2015).

126 United Nations Conference on Trade and Development, Trade, Misinvoicing in Primary: The Cases of Chile, Cote d'Ivoire, Nigeria (Geneva, 2016).

127 African Minerals Development Center, Impact of Illicit Financial Flows on Domestic Resource Mobilization: Optimizing Revenues from the Mineral Sector in Africa (Addis Ababa, 2017).

128 Max Everest, "The Political Economy of Controlling Tax Evasion and Illicit Financial Flows", eds. In Peter Reuter, Draining Development: Controlling the Flows of Illicit Funds from Developing Countries, pp. 69-109 (Washington, 2012). 
increasingly hard-to-attract investors with upwardly revised rates, ${ }^{129}$ the relatively low rates of royalties appears not to have translated into increased tax revenues for governments in Africa. ${ }^{130}$ Notably, the rates were set a long-time ago under pressure of the World Bank and key international financial institutions as a way of attracting investment.Even against the just ended surge in commodity prices, resource taxes including royalties fell from 41 per cent in 1980 to 37.1 per cent as a share of overall tax revenues in $2010 .{ }^{131}$ In truth, geology matters more than tax policies for attracting investors. According to an AfDB study, the most significant influence on the cost of operating a gold mine was grade quality, underscoring the influence of geology and geological information. ${ }^{132}$ Based on perceptions of business executives, the influential Fraser Institute reports that only 3.5 per cent of mining companies surveyed will not invest in Africa due to perceived constraints imposed by their tax regimes. ${ }^{133}$

Without a framework underpinned by equity and fairness, any governance effort will remain limited and ill-equipped to manage the complex challenges of the mining sector effectively. The Africa Mining Vision aims at transparent, equitable and optimal exploitation of mineral resources to underpin broad-based sustainable growth and socio-economic development. ${ }^{134}$ The Action Plan aims to optimize the share of mineral revenue accruing to resource-rich economies. And through the Country Mining Vision, African countries are developing fiscal instruments that are underpinned by fairness and equity.

\subsection{Policy Stream}

African mineral exporters are locked-in at the zero or lowest valueadding stage of the global mining industry. While the locus of mining

129 Ernest and Young, Business Risks Facing Mining and Metals 2015-2016. Ernest and Young. <http://www.ey.com/Publication/vwLUAssets/EY-business-risksin-mining-and-metals-2015-2016-new/\$FILE/EY-business-risks-in-miningand-metals-2015-2016-new.pdf>

130 World Bank, Mining Royalties: A Global Study of their Impact on Investors, Government and Civil Society (Washington D.C, 2006).

131 Mario Mansour, Tax Revenue Dataset for Sub-Saharan Africa 1980-2010 (International Monetary Fund, 2010).

132 African Development Bank, "Royalty Rates in African Mining Revistied: Evidence from Gold Mining", Africa Economic Brief (Tunis, 2012).

133 Fraser Institute, Survey of Mining Companies 2015. Fraser Institute (2016).

134 African Union, Africa Mining Vision (2009), p. 1. 
production moves rapidly to emerging countries, including African, the centres of value addition and beneficiation, key to industrialization and structural transformation, remain outside the continent. Most mining countries in Africa are not only getting the minimum from exporting their minerals in raw forms, but also limiting opportunities for greater employment generation, wealth diversification as well as leaving themselves vulnerable to volatilities of global resource markets. Annual fluctuation in prices for unprocessed ores averages 23 per cent against 13 per cent for those that are processed. ${ }^{135}$ Africa exports about 8 per cent of world's iron output but shares only 1 per cent of global steel production, the processed ore, dominated by South Africa. ${ }^{136}$ Yet Africa's potential for steel production is set to grow exponentially with recent discoveries of substantial iron ores in West Africa.

Despite the continent's mineral endowment, industrialization is failing to take root. African countries are unable to turn their natural resource advantages into engines for internationally competitive industrial and diversified economies. The share of manufacturing value added in African GDP has fallen over the years from 16.6 per cent in 1980 to 12.6 per cent in 2009 in sub-Saharan Africa. The values for North Africa have marginally increased from 12.6 to 13.6 per cent. ${ }^{137}$ In fact, Africa has even rolled backed its industrialization. ${ }^{138}$ Many more countries depend on exporting their minerals raw, a trend that has accelerated rapidly during the boom at the expense of developing vibrant, competitive manufacturing sector. Dependence on commodity exports as share of overall international trade has even increased over the years, from 0.24 in 1998 to 0.43 in $2011 .{ }^{139}$

The capacity to design and implement forward-looking policies aligned with the AMV remains a binding constraint. For example, a recent study has underscored a self-limiting framing of geological information in mining legislations across the continent as records rather

135 Economic Commission for Africa, Economic Report for Africa: Making the Most of Africa's Commodities: Industrializing for Growth, Jobs and Economic Transformation (Addis Ababa, 2013).

136 World Steel Association, "World Steel in Figures" (Brussels, 2014).

137 Economic Commission for Africa, Economic Report on Africa: Dynamic Industrial Policy in Africa (Addis Ababa, 2014).

138 Economic Commission for Africa, Economic Report for Africa: Making the Most of Africa's Commodities: Industrializing for Growth, Jobs and Economic Transformation (Addis Ababa, 2013).

139 Ibid. 
than dataset that could be aggregated and analysed for effective tracking and monitoring mineral exploration and production along the value chain. ${ }^{140}$ The report concludes on the argument that there is little clarity on the use of the terms "geological information", "geological knowledge", "geological data" and "geological records" in mineral codes in Africa. With the exception of South Africa, there is no requirement for precompetitive data submitted to government to be digitalized. Data submitted are often in PDF formats, which cannot be aggregated. As a result, African governments are failing to update their national geological data set, representing almost US\$1billion of data acquisition expenditure. ${ }^{141}$ African countries are not only losing money, but also opportunities to attract further investment to their mineral sector. Studies further show that precompetitive datasets, when made available to mineral exploration companies, could leverage inward investment from $3: 1$ to $20: 1$ for a number of jurisdictions. ${ }^{142}$

African countries are not taking advantage of boom periods to plan for the future. Resource extraction is heavy on capital and light on employment. Africa's growth is impressive in general and particularly for mineral exporting countries, however it has not translated into increased jobs or higher standards of living for the majority of the region's population. Inequality, as measured by Gini coefficient, increased from 2001 to 2012, the highest after Latin America. ${ }^{143}$ The mining sector's share of employment, which remains even the lowest, has dropped significantly from 1.5 per cent in 1975 to 0.9 per cent in 2010, in spite of the economic boom. Africa's output gap that is the difference between actual and potential growth, from 2001 to 2013 increased, suggesting the potential for purposeful policies for inclusive structural transformation through industrialization. ${ }^{144}$

With an underdeveloped industrial base, the gap with other regions has widened. Participation as raw commodity exporter in the mining

140 African Minerals Development Centre, "Impact of Illicit Financial Flows on Domestic Resource Mobilization: Optimizing Revenues from the Mineral Sector in Africa" (Addis Ababa, 2017).

141 World Bank, The Billion Dollar Map, Technical Report, Washington D.C., 2014).

142 Margretha Scott and Malcolm Jones, Management of Public Geoscience Data, International Mining for Development Center (Sydney, 2014).

143 African Development Bank, Income Inequality in Africa (Tunis, 2012).

144 Economic Commission for Africa, Overview of Recent Economic and Social Development in Africa: Industrialization for Inclusive and Transformative Development in Africa (Addis Ababa, 2014). 
global value chain further marginalizes Africa. The distance between other developing countries is not only broader but cumulative and path-dependent. ${ }^{145}$ Due to their diversified industrial base, Asian countries perform better with the same level of growth as Africa. A 10 per cent increase in national income translates into a 20 per cent reduction in poverty in Asia, against only a 7 per cent reduction in poverty in Africa. ${ }^{146}$ At the same time, firm-level survey data shows that formal manufacturing firms in Africa are generally more productive in terms of value added per employee when adjusted for levels of GDP per capita, suggesting the potential for manufacturing. ${ }^{147}$

Imported capital goods for the extractive sector show poor upstream linkages to the economy. Yet, increased downstream value-addition presents an opportunity to diversify and transform economies of mineral rich countries. A study by the Southern African Development Community (SADC) of the value chain for a range of minerals found that the value of processed products was typically 400 times greater than the equivalent unit value by weight of the raw material. ${ }^{148}$ Due to weaker forward, backward and sideward linkages of its mining industry, Africa accounts only for 1 per cent of global value added in manufacturing, the same share since 2000. ${ }^{149}$

Commodity-led development strategies are evolving and changing in Africa. Owing partly to the AMV, countries are adopting more development-oriented approaches toward the mining sector. ${ }^{150}$ While there is yet to be a systematic study of AMV implementation, many

145 LallSanjaya, "Industrial Success and Failure in a Globalizing World", International Journal of Technology Management and Sustainable Development, Volume 3, Number 3 (2004), pp. 189-214(26).

146 World Bank, "Lessons for Africa from China's Growth." Speech by the World Bank Group Vice President for the Africa Region. < http://www.worldbank.org/ en/news/speech/2015/01/13/lessons-for-africa-from-chinas-growth>

147 Alan Gelb, Christian J. Meyer, and Vijaya Ramachandran, Development as Diffusion: Manufacturing Productivity and Sub-Saharan Africa's Missing Middle, Center for Global Development (New York, 2014).

148 Economic Commission for Africa, Economic Report on Africa: Governing Development in Africa - The Role of the State in Economic Transformation (Addis Ababa, 2011).

149 United Nations Industrial Development, Fostering Industrial Development in Africa in the New Global Environment (Vienna, 2011).

150 Pedro Antonio, “The Country Mining Vision: Towards a New Deal," Mineral Economics (2015), pp. 1-8 
countries are already revising their mineral exploitation regimes to maximize development benefits, including beneficiation. ${ }^{151}$ The African Minerals Development Centre is supporting more than 20 African countries to implement varied priorities in the AMV. ${ }^{152}$ For example, Malawi, Sierra Leone and Lesotho have undertaken comprehensive reforms of their mineral sector in accordance with the AMV. Zambia has recently adopted a new mining code that aims for the broad-based development of the mining sector. Left on their own, market forces are unlikely to establish those critical industrialization linkages, because transnational companies already have their own external linkages which they will want to maximize for greater value and returns across their global value chains as a whole. Governments are seeking for an optimal mix of sticks and carrots for the mining industry: proactively identifying win-win opportunities for developing linkages into and out of the sector both at domestic and regional economies.

At the same time, increasingly firm-specific opportunities for linkages are emerging. Lead mining multinational companies in the value chain, have an active interest to promote linkages in areas outside of their core competences - defined as capabilities, which are unique to them, difficult to copy and valued by customers. ${ }^{153}$ Given the rational incentive to promote low cost, low inventory production, in addition to ensuring the constant availability of capital intensive equipment, many lead commodity firms may not only wish to outsource non-core competences, but also to near source them. Observably, success depends on contextual factors, including host country ability to design and implement active industrial policy in a forward looking manner and targeting cost-cutting imperatives of key multinational companies. For example, while there are still some challenges, Botswana is to strategically develop its downstream sector through partnering with De-beers, a leading multinational company to create a viable diamond cutting and polishing industry in the country. There were 16 diamond

151 Ernest and Young, "Business Risks Facing Mining and Metals 2015-2016". <http://www.ey.com/Publication/vwLUAssets/EY-business-risks-in-miningand-metals-2015-2016-new/\$FILE/EY-business-risks-in-mining-and-metals2015-2016-new.pdf>

152 African Minerals Development Centre, "PartnersReport", Unpublished (Addis Ababa, 2015).

153 Mike Morris, Raphel Kaplinsky and David Kaplan. 2012. One Thing Leads to Another: Promoting Industrialization by Making the Most of the Commodity Boom in Sub-Saharan Africa (Open University Press, 2012). 
cutting and polishing factories in Botswana in 2011, creating over 2500 jobs. ${ }^{154}$

Contextual constraints to climb the value-adding chain are at different levels in countries. The most notable impediments include poor infrastructure, limited finance, weak environmental regulations, trade barriers, lack of policy harmonization and regional markets. For example, due to lack of reliable electricity, Africa is losing 3-5 per cent of GDP every year. ${ }^{155}$ In fact, refining base metals alone will require almost 115 per cent of total electricity currently produced in Africa. ${ }^{156}$

While some African countries have developed industrial frameworks, most are yet to develop effective industrial policies. Many more have not sufficiently linked their industrial, minerals and trade policies in an integrated fashion. Most lack strategies and incentives on valueaddition that could maximize regional and continental growth opportunities. Consequently, the share of intra-African trade remains extremely low compared to other major regions. Over the period from 2007 to 2011, the average share of intra-African exports in total merchandise exports in Africa was 11 per cent compared with 50 per cent in developing Asia, 21 per cent in Latin America and the Caribbean and 70 per cent in Europe. Over the period 2007 to 2011, intraregional exports amounted to 10.9 per cent of world African exports and the share of intraregional imports stood at 12.7 per cent. ${ }^{157}$ However, the level of value addition in intraregional trade including minerals is far higher than Africa's trade with the rest of the world, suggesting the potential for structural transformation of economies through viable regional value chains. ${ }^{158}$

Notably, value addition in an inclusive approach remains central for viable industrialization. The AMV minerals focused development lays the foundation for buoyant sustained manufacturing in Africa. The emphasis on optimizing the full potential of all minerals, including the

154 Letsema Mbayi, Linkages in Botswana's Diamond Industry: Cutting and Polishing Industry (Open University, London, 2011).

155 Economic Commission for Africa, Economic Report on Africa: Dynamic Industrial Policy in Africa (Addis Ababa, 2014).

156 Economic Commission for Africa, Special Thematic Edition: Africa Economic Outlook, Structural Transformation and Natural Resources (Addis Ababa, 2013).

157 United Nations Conference on Trade and Development, Intra-African Trade: Unlocking Private Sector Dynamism (Geneva, 2013).

158 Economic Commission for Africa, Economic Report on Africa: Industrializing through Trade (Addis Ababa, 2015). 
often neglected minerals, clearly sets the AMV apart as an idea whose time has come. Consumption of low value minerals provides critical feedstocks and inputs for Africa's industrialization. Domestic manufactures from limestone and sand, minerals and commodities often neglected because of their low price, are not only demonstrating strong resilience but also remarkable transformative potentials of African economies. Cement manufactured on the continent from abundant limestone deposits is witnessing a spectacular growth at 5 per cent annual consumption, correlating strongly with Africa's GDP as well as suggesting minerals-based structural transformation. ${ }^{159}$ Based on multiple regression analysis, an independent industry research, suggests that a 1 per cent increase in locally manufactured cement leads to a 5.97 per cent increase in Nigeria's GDP growth. ${ }^{160}$

The same happens with phosphate, another low-value mineral used for manufacturing fertilizers. Phosphate prices have fallen globally, in line with depressing commodity prices while investment into the phosphate sector in Africa remains buoyant. The Office Cherifien des Phosphates, the Moroccan phosphate giant, reported revenues over the first half of 2015 totalling US\$2.5 billion, with second-quarter adjusted earnings pegged at US\$479 million. The company offset a temporary decline in Brazilian imports by almost doubling its sales within Africa. Consumption of low value minerals remains critical and is set to grow in Africa. Africa's consumption of fertilizer is the lowest in the world with per capita utilization of nine kilograms per hectare against a global average of 107 kilograms. Similarly per capita consumption of cement remains only at $100 \mathrm{~kg}$ per person as compared to the global average of 500kg. ${ }^{161}$

The cement sector is emerging in Africa thanks to AMV-like policies of local content and value addition. For example, the spectacular emergence of Nigeria as a net exporter of cement has happened thanks to focused local content policies for encouraging domestic manufacturing of cement. ${ }^{162}$ Consequently, Africa is experiencing its own

159 Ecobank, Middle Africa Insight Series on Commodities (Lagos, 2014).

160 Dunn Loren Merrifield, The Nigerian Cement Industry: Cement Industry Report, 11 September (Lagos, 2014), p. 54.

161 Maria Wanzala and Rob Groot, "Fertiliser Market Development in Sub-Saharan Africa" (International Fertiliser Society, 2013).

162 Moshood Ademola Fayemiwo and Margie Marie Neal, Aliko Mohammad Dangote: The Biography of the Richest Black Person in the World (Strategic Book Publishing and Rights, Houston, 2013). 
first world-class industrial conglomerate of continental reach. Strikingly, in the downbeat moment, when other mining companies are revisiting their strategies, the multi-billion dollar Dangote Cement Group is betting on Africa's future like never before, tripling its expansion across the continent. ${ }^{163}$

Nevertheless, activist industrial policies remain contentious in development thinking. ${ }^{164}$ The opportunities for downstream beneficiation of high value minerals remains a challenge. The AMV frames optimal beneficiation in terms of supporting the development of viable regional value chains. Most criticisms of the AMV prioritization of downstream beneficiation fail to take into consideration the regional dimension. Taking South Africa as an example, a recent report criticized AMV-like value addition policies for generating rent-seeking incentives for suboptimal institutional choices incongruent with optimal development practice. ${ }^{165}$ Based on selected list of case studies from the Southern African region (SADC), country case studies, Grynberg and Sekakela (2015) flag pitfalls of beneficiation in base metals, given the compression in smelting, refining and semi-fabricate margins since 2004-2005 by China's active industrial policy on local content. ${ }^{166}$

In contrast, to most criticisms, the AMV policy interventions are focused on the demand-side. The Vision is to create international competitive mining economies in Africa, by correcting market failures in regional integration processes for the emergence of viable regional value chains in mining. The continental framework aims to facilitate the emergence of efficient regional markets for critical feedstocks at a price and on a scale that are competitive to support industrialization. In fact, the AMV takes the regional level as a decisive point for developing and implementing productive linkages through beneficiating minerals and supporting local manufacturing of inputs for the mines.

163 African Business. 2015a. "Aliko Dangote: Africa Will Deliver on its Promise" (October 2015).

164 Ha-Joon Chang, Industrial Policy: Can Africa Do It? IEA/World Bank Roundtable on Industrial Policy in Africa (2012); Justin Lin, The Quest for Prosperity: How Developing Countries Can Take Off (Princeton University Press, 2012).

165 Ross Harvey, "Mineral Rights, Rents and Resources in South Africa's Development Narrative", Occasional Paper 224 (South African Institute of International Affairs, 2015).

166 Roman Grynberg and Kedibonye Sekakela, "Case Studies in Base Metal Processing and Beneficiation: Lessons From East Asia", Research Report 21, December (South African Institute of International Affairs, 2015). 


\subsection{Politics Stream}

A confluence of periodic and random events is coming together to create a momentum for change. The sense of crises in the extractive sector is set against a background of emerging opportunities at different levels, with implications for the Africa Mining Vision. The politics stream is influenced by dynamics in the international and domestic political economy.

A seemingly new era of development thinking and interventions is emerging, even though it is still unclear how it will progress. The recently adopted Sustainable Development Goals (SDG) will guide global efforts, including those in Africa, to achieve inclusive and structural transformation of economies in the next 15 years. Unlike the just ended Millennium Development Goals, the goals, target important challenges to structural transformation of African countries with implications for the AMV. The 17 goals and 169 targets underpin principles of fairness and empowerment, core ideas in the AMV. Specifically, member states commit to reducing illicit financial flows as well as supporting countries to integrate greater into value chains and markets. This remains a conjecture because how do we know that this is going to change the economic landscape. What we need to know is whether an alignment is taking place between AMV and the SDGs.

The strong emphasis on domestic resource mobilization resonates with the AMV paradigm of fairness and empowerment to effectively mobilize and share revenues from Africa's minerals. The financing framework for the long-term goal, the Addis Ababa Action Agenda, further stresses the importance of domestic resource mobilization with taxation appearing 36 times in the document endorsed by member states. The report underlines key principles and tenets of AMV, including "encourage investment in value addition and processing of natural resources and productive diversification". Member states also commit to addressing"excessive tax incentives ... to investment in extractive industries". ${ }^{167}$ The developmental state through industrial policy was reaffirmed. ${ }^{168}$

167 United Nations, Addis Ababa Action Agenda for Financing the Post-2015 Development Goals. Report on Financing for Development (Addis Ababa, 2015), p. 4.

168 Ibid, p. 6. 
Tax transparency is also getting further international traction, with the adoption of the Base Erosion and Profit Shifting proposals by OECD and G20 countries (OECD, 2013). The 15 Action Points remain so far the most comprehensive attempt at reforming the broken system of international tax governance in about 100 years. ${ }^{169}$ The proposal addresses loopholes for abusive transfer pricing and beneficial ownership, major sources of uncontrolled cross-border leakages of much needed potential tax revenue from the extractive sector in Africa.

Nevertheless, Africa's ability to take advantage effectively of the emerging global opportunities will depend on key dynamics in the international political economy. While Africa participated in a systematic and proactive manner in shaping the Post-2015 development agenda, ${ }^{170}$ its role in influencing the OECD-led reforms of the international tax system remains marginal. ${ }^{171}$ As a result of limited participation of African countries in the formulation of the adopted international tax rules, the continent's core interests and key priorities for domestic resource mobilization remain unaddressed in the adopted OECD Base Erosion and Profit Shifting Action Plan. ${ }^{172}$ For example, specific and significant risks of cross-border fiscal leakages from the mineral sector, including generous tax exemptions that mining companies have explored to the disadvantage of the host countries, are not included in the package of reforms adopted.

While steps have been taken to ensure that BEPS implementation is more inclusive, the fundamental weaknesses of the international fiscal system remain unaddressed, and this significantly disadvantages mineral-rich African countries. In fact, the underlying unfair 1920s compromise for allocating the rights to tax cross-border operations of multinational companies remain unchanged. ${ }^{173}$ This compromise favours

169 Organization of Economic Cooperation and Development and Group of Twenty Countries (OECD), OECD-G20 Base Erosion and Profit Shifting: Explanatory Statement (Paris, 2015).

170 African Union Commission, Africa Common Position on the Post 2015 Development Agenda (Addis Ababa, 2014).

171 African Tax Administration Forum, "Crossborder Taxation: Challenges and ATAF's Response, Presentation at the 4th International Workshop on Domestic Resource Mobilization" (Pretoria, 2015).

172 Ibid.

173 Michel Devereux and John Vella, "Are We Heading Towards a Corporate Tax System Fit for the 21st Century?" Fiscal Studies, Vol. 35(4) (2014), pp.449475. 
capital exporting countries with greater taxing rights over capital importing countries.

The ruling elites in mineral-rich countries in Africa have often explored the loopholes in international tax system to transfer funds from the sector abroad illicitly. The recently infamous leaks of financial information held by major banks in Panama, a tax haven, unveiled a list of 18 leading government officials from key mineral-rich countries with multimillion dollar bank accounts in the secrecy jurisdiction. ${ }^{174}$ The New York Times recently confirmed the widespread use of Shell companies by some high-level business and government elites in Africa to facilitate shifting of their ill-gotten wealth from the mineral sector to tax havens abroad. ${ }^{175}$

Successfully implementing the AMV would depend on the extent to which countries can address key binding constraints to diversification. Meanwhile, the rules of the game in particular the goal posts of value creation and benefits sharing in the global value chains are changing. Governance of minerals value chains is becoming more sophisticated and complex with risks of further marginalizing African minerals producers. Authority and power relationships that determine how value is produced and allocated along different activities within international production networks are evolving, rapidly. ${ }^{176}$ Value creation in chain governance is increasingly decoupling from where production activities are taking place. ${ }^{177}$

174 Ghana Pulse, "Africans Named in Major Leaks". <http://pulse.com.gh/ international/panama-paper-all-the-18-africans-named-in-major-leakid4880206.html > Retrieved on 4 April 2016.

175 New York Times, "Panama Papers Reveals Wide Use of Shell Companies by African Officials”. <http://www.nytimes.com/2016/07/25/world/americas/ panama-papers-reveal-wide-use-of-shell-companies-by-africanofficials.html?mwrsm=Email\&_r=0: http://www.nytimes.com/2016/07/25/ world/americas/panama-papers-reveal-wide-use-of-shell-companies-byafrican-officials.html?mwrsm=Email\&_r=0 $>$ Retrieved on 25 July, 2016.

176 Garry Gereffi, John Humphrey and Thomas Sturgeon, "The Governance of Global Value Chains", Review of International Political Economy (2005), pp.78104.

177 Organization of Economic Cooperation and Development (OECD). "Examples of Successful Domestic Resource Mobilization Reforms and the Role of International Cooperation", Discussion Paper (Paris, 2015). 
In fact, value addition activities are increasingly less aligned with productive activities but more with the ownership of intangible assets like intellectual property and patents. While productivity in the mining industry halved over the last two decades ${ }^{178}$ patents fillings by industry surprisingly has not only resisted, but also increased entirely. ${ }^{179}$ The trend underpins an opacity that favours multinational companies who own the key capital assets. ${ }^{180}$ This leads to a rise in intangible assets as the value creators artificially increases the barrier for African countries to upgrade sustainably and earn commensurable returns for their participation within the global value chain. ${ }^{181}$ "The solution searched for by capital is now to advance rights to intellectual property in order to collect monopoly rents." 182

The international frameworks governing minerals resources are becoming increasingly complex with the proliferation of overlapping and conflicting initiatives ${ }^{183}$ underpinned by vested interests, which risks undermining efforts to implement the AMV. While compliance remains largely voluntary, some responsible mining initiatives are mandatory. Almost all of them operating in Africa are driven externally outside the continent. A recent white paper by the World Economic Forum identified over 40 voluntary responsible mining initiatives which are all aspirational, issue-focused, commodity-focused and site-based. ${ }^{184}$

While a patchwork of externally driven responsible mining initiatives seems to open space for competition of ideas, they are

178 Ernest and Young, "Productivity in Mining: Now Comes The Hard Part", A global survey (E\&Y, 2014). < http://www.ey.com/Publication/vwLUAssets/ EY-productivity-in-mining-now-comes-the-hard-part/\$FILE/EY-productivityin-mining-now-comes-the-hard-part.pdf $>$

179 Francis Emma, F. 2015. The Australian Mining Industry: More than Just Shovels and Being Lucky (Canberra: Commissioned by IP Australia).

180 Claude Serfati, "Financial Dimensions of Transnational Corporations, Global Value Chain and Technological Innovation". Journal of Innovation Economics and Management, Vol. 2 (2008), pp. 35-61.

181 Ralph Kaplinsky, "Globalization and Unequalization: What Can Be Learned From Value Chain Analysis," The Journal of Development Studies, Vol. 37, 2 (2000), p. 117.

182 Carlo Vercellone, The New Articulation of Wage, Rent, Profit in Cognitive Capitalism (Queen Mary University, London, 2008), p. 20.

183 McKinsey, The Global Nature of Mining \& Metals, (McKinsey and Company, 2009).

184 World Economic Forum. 2016. Voluntary Responsible Mining Initiatives: A Review (Geneva, 2016). 
stretching thin the already limited resources for implementing countryowned, continentally agreed vision for the mineral sector. The agendas of most of these initiatives are too narrow and misaligned with the comprehensive priorities adopted by countries for the broad-based development of the minerals sector. In fact, the dangers of "initiative fatigue" is real and underscored through the lack of linkages between the different initiatives, increased transaction costs, and displacement of capacities in countries. ${ }^{185}$ Implementation requires focused efforts at overcoming the vested interests in the way of achieving the AMV.

Despite the proliferations of governance frameworks, there is still a strong demand for AMV-type initiatives. According to a recent WEF global survey of stakeholders in the mining sector, the majority of respondents expressed a need for more comprehensive initiatives in particular those that can tackle emerging challenges facing the sector, including commodity price collapse. ${ }^{186}$ Furthermore, while regulations were cited as a major driver, it is surprisingly curbing illicit financial outflows, including abusive transfer pricing that wasnot a priority area for mineral governance.

Africa continues to project its agency through ownership of development agenda, with mixed outcomes. The African Union and its Member States have adopted Agenda 2063, which incorporates the AMV as the pillar for achieving structural transformation of economies through the broad-based development of the minerals sector. ${ }^{187}$ Member States have committed to implementing both the UN Agenda 2030 and AU Agenda 2063 in an integrated and coherent manner. ${ }^{188}$ While both agendas overlapped in most priority areas, there are some differences, including scale of priorities and calendar of implementation. Notably, the traditional dependence on aid and potential of disproportionate donor resources going to support countries to achieve the United Nations global goals may marginalize the implementation of the AU Agenda 2063, the continentally owned framework.

185 Ibid, p. 4.

186 Ibid.

187 African Union Commission, Executive Council, Twenty-Sixth Ordinary Session (Addis Ababa, 2015).

188 Economic Commission for Africa and African Union Commission, "Ministerial Statement on the Economic Commission for Africa, Conference of African Ministers of Finance Planning and Economic Development Forty Nine Session" (Addis Ababa, 2016). 
African countries will need to sustain their position; most continental initiatives continue to depend heavily on external funds for their implementation, which often are misaligned with agreed priorities of Member States. While efforts have increased significantly in the continent to generate own resources to support key initiatives, success remains a work in progress. For example, the AU's operational budget is funded almost entirely from donor's contributions. In fact, Member States finance only 33 per cent of the US\$428 million budget. ${ }^{189}$ The initial funding for the African Minerals Development Centre responsible for implementing the AMV was provided by Canada and Australia. ${ }^{190}$

However, the African Union has recently adopted a proposal to generate internal resources from the continent in a sustainable manner to finance the Union and its continental initiatives (AUC, 2016). The new financing model, which is due to be implemented in 2017, aims to levy a 0.2 per cent tax on imports to the continent towards financing AU operations. Besidesadministrative complexity that challenges implementation, overcoming real politics often played by member states will be crucial.

The AMV will need to facilitate the emergence of inclusive panAfrican identities around mineral value chains based on economic interests around linkages, and do so in ways that organize citizens, communities and elites for the transformation of the continent. How to mutuallycombine political and economic identities, as well as territorial based identities anchored around maximizing rents with economic identities anchored in optimizing productive activities within value chains remains a challenge. While mining remains a site-based activity, value creation occurs through linkages, which may be misaligned with electoral maps and election cycles. Pursuing a strategy of broadening linkages with the rest of the economy may go against the narrow expectations of voting constituencies of the ruling elites. For example, a regional-based approach to developing key infrastructure linkages with the Simandou Iron Ore Project, the largest integrated

189 African Union Commission, Executive Council, "Twenty-Sixth Ordinary Session" (Addis Ababa, 2015).

190 Africa Minerals Development Centre, "Partners Report", Unpublished (Addis Ababa, 2015). 
mining and infrastructure project contemplated in Africa, remains optimal. ${ }^{191}$

Observably the Government of Guinea allegedly "pressured Rio Tinto to route the rail link through Conakry" which offer limited linkages but high potential to maximize electoral gains for the Government than the initial proposal to route the planned railway through Liberia with potential for maximum development returns. ${ }^{192}$ The rail link through Liberia will benefit both countries and the region more in economic terms and would require only upgrading and minimal extension, as opposed to building a new $700 \mathrm{~km}$ line at a cost of approximately US $\$ 10$ billion through Conakry. ${ }^{193}$

Leveraging the transformative potential of minerals will require nudging domestic elites - ruling, business and bureaucrats - towards a shared vision and interests in taking advantage of mineral value chains. Yet altering local power dynamics and relationships between different groups and interests for the broad-based transformation of the minerals sector requires more than a technical policy fix. It remains highly political and complex, with far-reaching implications on local, national and regional politics.

Effective local content strategies remain a test bed for transforming power relations in the mining sector. Policies to encourage mining companies to procure inputs locally provide an opportunity for integrating the sector within the local, national and regional economies. While most mineral-rich African countries have adopted local content policies, success remains mixed. ${ }^{194}$ As a result of vested interests in part, local content strategies are framed narrowly around domestic ownership rather than extent of local value addition within national economies. ${ }^{195}$ Most countries are yet to incorporate the regional dimension in their local content policies, despite the obvious benefits. ${ }^{196}$

191 SOGUIPAMI, "Local Content Policy for the Simandou: Integrated Mining and Infrastructure Project", Republic of Guinea (Conakry, 2015).

192 South African Institute of International Affairs, "Mining for Development in Guinea: Examination of the Simandou Iron Ore Project", SAIIA Policy Brief 83 (2015), p. 4.

193 Ibid.

194 Isabelle Ramdoo, Local Content Policies in Mineral-rich Countries: An Overview, European Center for Development Policy Management (Maastricht, 2016).

195 World Bank, Increasing Local Procurement by the Mining Industry in West Africa, Report No. 66585-AFR (Washington, 2012).

196 Isabelle Ramdoo, Local Content Policies in Mineral-rich Countries: An Overview, European Center for Development Policy Management (Maastricht, 2016). 
As the light of transparency shines brighter on revenue management, local content appears to emerge as a new black box for elite rent seeking, undermining the potential for broad-based transformation of economies. In examining the political economy of mining in Africa, Hansen, et al (2015) argue that the current power balance in the domestic elites' constellations is sustained by capturing rents from the sector. ${ }^{197}$ And transforming the relationship away from rents to sustainable revenue mobilization through productive and higher value adding activities may threaten clientele settlements between business and politics as well as stability of regimes in countries. ${ }^{198}$

The merchant class of traders and importers heavily dominate business and political relationships in Africa. Arguably an inheritance of colonialism, the industrialist business class in Africa with genuine interests to take advantage of linkages through manufacturing remain marginalized and almost absent in most countries. ${ }^{199}$ Local content provides a transformative opportunity to change the structure of economies by actively encouraging the emergence of local entrepreneurs committed to manufacture inputs into the mines. Buur (2014) shows how local content policies in Mozambique have been captured by elites who used their privileged access to information and power to create small and medium size enterprises just for the sole purpose of capturing contractsto import supplies to the mining industry, at the expense of genuine entrepreneurs with capability to manufacture inputs locally. ${ }^{200}$ Using Ghana as case study, Ablo (2016), concludes that while local content laws have been beneficial to local elites, it has not stimulated broad-based social and economic transformations. ${ }^{201}$ He further argues that embedded power relationship among elites have shaped the outcomes away from value addition to rent seeking. Based on

197 Michael W. Hansen, Lars Buur, Ole Therkildsen and MetteKjær. 2015. "The Economics and Politics of Local Content in African Extractives: Lessons from Tanzania, Uganda and Mozambique", Forum for Development Studies, Vol. 42, No. 3 (2015).

198 Mushtaq Khan, Political Settlements and the Governance of Growth-Enhancing Institutions (SOAS, London, 2010).

199 Ibid.

200 Lars Buur, The Development of Natural Resources Linkages in Mozambique: The Ruling Elite Capture of New Economic Opportunites, Danish Institute for International Studies, Working Paper 03 (2014).

201 Austin Ablo, "From Local Content to Local Participation" (University of Bergen, Ph.D Thesis, 2016). 
experiences in Angola, Amundsen (2014) observes that domestic entrepreneurs with genuine interests to take advantage of productive linkages need in addition to their ideas, capacity and finance support from patronage networks of power and rent-seeking to succeed. ${ }^{202}$

Overcoming the political economy constraints requires a strong constituency for change. Engagement of the discourse community, knowledge networks and advocacy coalitions in Africa around AMV priorities for broad-based development of the mining sector remains limited. Since its adoption in 2009, very few peer reviewed articles on the AMV have been published. In addition, successful implementation will require strengthening the capacity of African-based nongovernmental organizations and community-based groups in particular on issues around linkages and value addition through beneficiation. So far, accountability, environment and human rights issues around mining dominate the activities of most NGOs operating on the continent. Marginal work exists on the linkages and spatial dimensions of mining, which is at the heart of the AMV.

\section{POSSIBLE CHANGE SCENARIOS}

How all three streams add up in ways that effectively open windows for change remains complex, dynamic and difficult to predict with certainty. The outcomes depends on varied factors including how the AMV ideational foundation is capable of organizing interests, institutions, actors and power for change. To examine possible trajectories of change, we appeal

to the Boin et al (2009) policy change framework. A two by three matrix of key independent variables applies (see Figure 2). Based on different permutations of path to change, six possible AMV scenarios are identified.

202 Inge Amundsen, "Drowning in Oil: Angola's Institutions and the Resource Curse", Comparative Politics, Vol. 46, No. 2 (2014), pp. 169-189. 


\begin{tabular}{|c|c|c|}
\hline & $\begin{array}{l}\text { Advocate for AMV } \\
\text { Incremental }\end{array}$ & $\begin{array}{l}\text { Advocate for AMV } \\
\text { Wholesome }\end{array}$ \\
\hline Resist Policy Change & $\begin{array}{l}\text { Scenario I. Partially } \\
\text { Unlikely } \\
\text { Stalement/politically } \\
\text { imposed incremental } \\
\text { AMV change. }\end{array}$ & $\begin{array}{l}\text { Scenario II. Very unlikely } \\
\text { Stalement/politically imposed } \\
\text { AMV paradigm shift. }\end{array}$ \\
\hline $\begin{array}{l}\text { Contain Policy } \\
\text { Change }\end{array}$ & $\begin{array}{l}\text { Scenario III. Very } \\
\text { Highly Likely } \\
\text { Negotiated incremental } \\
\text { adjustment to take } \\
\text { into consideration } \\
\text { some AMV core ideas } \\
\text { and mechanisms for } \\
\text { implementation. }\end{array}$ & $\begin{array}{l}\text { Scenario IV. Likely } \\
\text { Major swift rhetorical/ } \\
\text { symbolic change, but no } \\
\text { fundamental shift towards } \\
\text { adoption of AMV 'deep core' } \\
\text { ideas, principles and tenets. }\end{array}$ \\
\hline $\begin{array}{l}\text { Accept Policy } \\
\text { Change }\end{array}$ & $\begin{array}{l}\text { Scenario } V \text {. Very } \\
\text { likely } \\
\text { AMV principles and } \\
\text { tenets selectively } \\
\text { implemented on } \\
\text { incremental basis. }\end{array}$ & $\begin{array}{l}\text { Scenario VI. Partially } \\
\text { likely }\end{array}$ \\
\hline
\end{tabular}

Figure 2

\section{CONCLUSIONS}

Following the current commodity slump, the Africa Mining Vision faces its greatest ever challenge since the African Heads of States adopted it in 2009. This paper assessed the ideational foundation of the AMV in the context of the depressed and volatile markets for minerals as well as the continent's priority for structural transformation of economies through minerals-based linkages.

It argued that the crunch presents an opportunity for African countries to implement AMV as a forward-looking, multidimensional paradigm that goes beyond maximizing revenues from commodity cycles. The article shows that the AMV is underpinned by a robust ideational foundation capable of steering governments through commodity downturns by building lasting institutions for broad-based development of the mineral sector.

Based on a multivariate model of policy change, problem, policy, and politics, as well as interests-based networks, the article developed a dynamic conceptual framework to assess the potential of establishing 
the AMV as a paradigm whose time has come. The crisis presents an opportunity, which the article analyses emphasizing the binding political economy constraints African governments will have to overcome at the global, regional and country levels in order to implement the transformative ideas of the AMV.

A matrix systematically analysing possible scenarios in the way of implementing the Africa Mining Vision is presented. While AMV remains a paradigm whose time has come for extractive-led development strategies, its implementation would likely be non-linear. Resistance to change and different contexts of countries could lead to an incremental implementation of AMV. 